Illinois State University

ISU ReD: Research and eData

Theses and Dissertations

$4-2-2018$

\title{
Athletic identity, institutional support services, and transition factors: An analysis of student-athlete perceptions and implications
}

John Nowak Kaczorowski

Illinois State University, john.kaczorowski@gmail.com

Follow this and additional works at: https://ir.library.illinoisstate.edu/etd

Part of the Sports Management Commons

\section{Recommended Citation}

Kaczorowski, John Nowak, "Athletic identity, institutional support services, and transition factors: An analysis of student-athlete perceptions and implications" (2018). Theses and Dissertations. 866. https://ir.library.illinoisstate.edu/etd/866

This Thesis is brought to you for free and open access by ISU ReD: Research and eData. It has been accepted for inclusion in Theses and Dissertations by an authorized administrator of ISU ReD: Research and eData. For more information, please contact ISUReD@ilstu.edu. 


\section{ATHLETIC IDENTITY, INSTITUTIONAL SUPPORT SERVICES, AND TRANSITION FACTORS: AN ANALYSIS OF STUDENT-ATHLETE PERCEPTIONS AND IMPLICATIONS}

\section{JOHN NOWAK KACZOROWSKI}

74 Pages

Brewer, Van Raalte and Linder (1993) defined the term athletic identity as the degree to which a person identifies with the role of an athlete and seeks outside acknowledgement of that role. Those who have a high athletic identity tend to be those who have achieved elite levels within athletics. These elite athletes tend to base their self-worth and self-esteem on their ability, performance and the appreciation of their athletic talent, while gradually neglecting other aspects of psycho-social development (Cieslak II, 2004). These resulting deficits have been attributed to what is called identity foreclosure in the literature. High-stakes athletes can tend to take a shortterm outlook rather than focusing on their post-sport careers. This aversion to long-term and transitional planning can have tremendous behavioral and psycho-social consequences resulting from individuals' inability to identify as anything other than an athlete.

This cross-sectional, exploratory, survey study recorded athletic identity scores, perceived value ratings of support services, and a career situation inventory to ascertain relationships between these factors. One-way ANOVAs and Spearman correlations were utilized to identify differences between traditional interest groups for each component as well as to provide preliminary relationships between the dependent variables. Significant differences were 
detected between groups and correlations between athletic identity, perception of support services, and transitional career components were identified.

KEYWORDS: Athletic Identity; Career Situation; College Athletics; College Sport; Social

Identity; Student-Athlete Development 


\section{ATHLETIC IDENTITY, INSTITUTIONAL SUPPORT SERVICES, AND TRANSITION \\ FACTORS: AN ANALYSIS OF STUDENT-ATHLETE PERCEPTIONS AND IMPLICATIONS}

JOHN NOWAK KACZOROWSKI

A Thesis Submitted in Partial Fulfillment of the Requirements for the Degree of

\section{MASTER OF SCIENCE}

School of Kinesiology and Recreation

ILLINOIS STATE UNIVERSITY 
(C) 2018 John Nowak Kaczorowski 


\section{ATHLETIC IDENTITY, INSTITUTIONAL SUPPORT SERVICES, AND TRANSITION}

FACTORS: AN ANALYSIS OF STUDENT-ATHLETE PERCEPTIONS AND IMPLICATIONS

JOHN NOWAK KACZOROWSKI

COMMITTEE MEMBERS:

Rebecca M. Achen, Chair

Michael A. Mulvaney

Scott W. Pierce 


\section{ACKNOWLEDGMENTS}

I would like to begin by acknowledging the hard work, encouraging guidance, and thoughtful insight of my thesis committee members, Dr. Rebecca Achen, Dr. Michael Mulvaney, and Dr. Scott Pierce. Your mentorship through this process and the skills and experience you helped me to acquire are gifts I will carry with me throughout my career. An additional thank you to my advisor and committee chair is also due. Dr. Achen, your willingness to share your valuable time, energy, and expertise with me over my time in the program has enabled me to unlock and develop skills I never thought I'd have. To Dr. Clinton Warren, whose encouragement led me to the sport management program in the first place, thank you for the opportunity to explore new facets of my passion and consistently providing me with the tools to do so. To Professor Dawn Sanner, Dr. Karen Dennis, and the rest of the faculty and staff in the Kinesiology and Recreation department with whom I've had the pleasure of studying, thank you for the diversity and depth of your knowledge and the earnestness with which you share it.

Finally, I would be remiss if I didn't mention my overwhelming gratitude for my wife, Tara. You have been selfless and relentless in your support of my - and, by extension, our - new trajectory through life and without you, none of this would have been possible. Thank you for so much more than I have the space to mention here. We're one step closer to our goal of receiving a piece of mail addressed to "The Doctors Kaczorowski."

J.N.K. 


\section{CONTENTS}

Page

ACKNOWLEDGMENTS

TABLES $\quad$ v

CHAPTER I: INTRODUCTION 1

CHAPTER II: LITERATURE REVIEW 4

$\begin{array}{ll}\text { Social Identity Theory } & 4\end{array}$

Athletic Identity and Identity Foreclosure $\quad 5$

$\begin{array}{ll}\text { Personal Preparedness Post-Athletics } & 7\end{array}$

$\begin{array}{ll}\text { NCAA Programming and Directives } & 10\end{array}$

Need for Examination of Student-Athlete Perceptions 12

$\begin{array}{ll}\text { CHAPTER III: METHOD } & 14\end{array}$

$\begin{array}{ll}\text { Participants } & 14\end{array}$

$\begin{array}{ll}\text { Population } & 14\end{array}$

$\begin{array}{ll}\text { Sample } & 14\end{array}$

$\begin{array}{ll}\text { Institutional Service Profile } & 15\end{array}$

$\begin{array}{ll}\text { Instrument Development } & 16\end{array}$

$\begin{array}{ll}\text { Instrument Construction } & 17\end{array}$

$\begin{array}{ll}\text { Content Validity } & 18\end{array}$

$\begin{array}{ll}\text { Independent Variables } & 18\end{array}$

Division I Athlete (D1Ath) 19

$\begin{array}{ll}\text { Scholarshipped Athlete (Schol) } & 19\end{array}$

Male Athlete (Male) $\quad 19$ 
Revenue Sport Athlete (RevSp) 19

Minority Athlete (Min) 19

Athletes with Sport- and/or Recreation-Related Majors (SportMaj) 19

$\begin{array}{ll}\text { Dependent Variables } & 20\end{array}$

$\begin{array}{ll}\text { Athletic Identity (AI) } & 20\end{array}$

$\begin{array}{ll}\text { Perceptions of Support Services (PV) } & 20\end{array}$

SACSI Factors $\quad 21$

$\begin{array}{ll}\text { Analysis of Data } & 21\end{array}$

CHAPTER IV: RESULTS 23

$\begin{array}{ll}\text { Reliability } & 23\end{array}$

Athletic Identity, Perceptions of Supports, and Career Situation 24

$\begin{array}{ll}\text { Athletic Identity } & 24\end{array}$

Perceived Value of Support Services $\quad 24$

$\begin{array}{ll}\text { Perceived Career Situation } & 25\end{array}$

Differences in Identity and Perceptions $\quad 25$

$\begin{array}{ll}\text { Athletic Identity } & 26\end{array}$

$\begin{array}{ll}\text { Perceived Value of Supports } & 27\end{array}$

$\begin{array}{ll}\text { SACSI } & 32\end{array}$

Relationship Among Dependent Variables 36

Athletic Identity and PV of Supports 37

Athletic Identity and SACSI Factors 37

SACSI Factors and PV of Supports $\quad 37$

CHAPTER V: DISCUSSION 40 
Differences Between Groups

Divisional Level and the Relationship Between Identity, Valuation, and Transition Factors 42

Perception of Support Service Value 43

Transition Factors Between Groups $\quad 44$

Institutional Recommendations $\quad 45$

CHAPTER VI: LIMITATIONS AND FUTURE RESEARCH 47

CHAPTER VII: CONCLUSION

REFERENCES

$\begin{array}{ll}\text { APPENDIX A: SURVEY INSTRUMENT } & 61\end{array}$

APPENDIX B: SACSI FACTOR SCORING KEY 


\section{TABLES}

Table

Page

1. Participants by Grouping Factors 15

2. Reliability 23

3. Sample Size, Mean, Standard Deviation, and Range for the Dependent Variables 25

4. Differences in Athletic Identity Scores Among Interest Groups 27

5. Differences in Perceived Value of Supports Among Interest Groups 31

6. Differences in SACSI Factor Scores Among Interest Groups 35

7. Pearson Correlations Between Dependent Variables 39 


\section{CHAPTER I: INTRODUCTION}

As society's expectations for college-educated adults continue to evolve, there is a general sense that the preparation in these institutions of higher education evolve in kind. There seems, however, to be a higher societal demand upon those students participating in elite collegiate athletics. The NCAA and collegiate institutions have created and implemented services designed to assist and support student-athletes. However, researchers suggest that many student-athletes do not fully utilize these services for a variety of reasons (e.g. Adams, Coffee, \& Lavallee, 2015; López \& Levy, 2013; Watson, 2006). Some researchers even suggest that institutions can create a culture of disuse of services by student-athletes (e.g. Banwell \& Kerr, 2016; Horton, 2011; Rankin et al., 2016). This has been argued as a detriment of their on- and off-field self-efficacy, and long-term social, mental, emotional, interpersonal, and career development and health (e.g. Brown, Goehlert, Director, Graphics, \& Seifert, 2014; DiPaolo, 2017; Vickers, 2013). Many student-athletes have forged their identities in sport and may require more opportunities for support to avoid the foreclosure of other elements of self and develop healthy, transitional life and career skills.

It is pertinent to begin by examining cultural demands upon those with the largest societal spotlight in the American sport pantheon. With the exponential increases in exposure and subsequent increases in revenue related to collegiate sport, the role and societal perceptions and expectations of the collegiate student-athlete are changing (Dee, 2014; Osborne, 2014). NCAA Division I revenue are exceeding the $\$ 9$ billion mark (Gaines, 2016), and college tuition and fees are rising exponentially (averaging roughly $\$ 10,000$ and over $\$ 30,000$ for four years at public and private institutions respectively), causing many to question the emphasis put on athletics versus academics (Schoen, 2015). This has also driven much debate as to why even more dollars 
should be allocated for services to those who may already be publicly perceived to have unfair benefits due to their status as student-athletes.

There has been much scrutiny placed on these burgeoning iconic figures, and although much is being demanded from this population to whom much is given, many have indicated they are vastly underprepared for their celebrity and eventual transition to more traditional societal roles once their careers are over (Lally, 2007). Athletes cite an inability to appropriately handle perceived social and familial obligations and pressures associated with sharing their newfound status and potential for future wealth via sport (Corben, 2012). This increased scrutiny is acutely felt by those athletes in collegiate sport who may have all or portions of their academic costs covered resulting from their athletic ability/skill. This can create incongruences of purpose for athletes attending these institutions on that basis.

Many even express doubts about the validity of the assertion their off-field development has any priority in their tenure at the institution. Highly-touted, NFL-caliber-prospect quarterback, Josh Rosen, at a traditional college football power school, the University of California Los Angeles (UCLA), had this to say in a recent interview:

Football and school don't go together. They just don't. Trying to do both is like trying to do two full-time jobs. There are guys who have no business being in school, but they're here because this is the path to the NFL. There's no other way. Then there's the other side that says raise the SAT eligibility requirements. OK, raise the SAT requirement at Alabama and see what kind of team they have. You lose athletes and then the product on the field suffers. (Hayes, 2017)

Rosen goes on to discuss the value he sees in education, despite acknowledging his perception of his role at UCLA as mostly an athletic one. Not all star-players feel the same way. Cardale 
Jones, who gained notoriety when he quarterbacked the Ohio State University (OSU) to a National Championship in 2014, had this to say via Twitter his freshman year: "Why should we have to go to class if we came here to play FOOTBALL, we ain't come [sic] to play SCHOOL, classes are POINTLESS." While this attitude highlights the frustration some athletes feel when trying to balance both aspects, the good news here is, despite being drafted and currently playing in the NFL, Jones went back to OSU and graduated (Wilson, 2017).

Cardale Jones admits he has come a long way when it comes to his maturity and seeing value in a college education (Wilson, 2017). However, he left OSU when his playing days finished in 2015 without graduating. Jones has received paychecks from the NFL in the twoyear interim between his jump to professional sport and his return to finish school, but the overwhelming majority of student-athletes do not attain professional athlete status, nor pay (Powell, 2017). This can force players who have developed an identity with sport at its core, into making tough decisions about which programs to pursue, which courses to take, and how to allocate their minimal time and resources.

These pressures can lead to athletes making decisions to serve one aspect - athletics - of their collegiate experiences and foreclose on other elements of their personal and future career development (Martens \& Cox, 2000; McQuown Linnemeyer \& Brown, 2010). The goal of this study is to explore whether seeing oneself as an athlete first can impact student-athlete perceptions of services offered to help them develop other aspects of self- and careerdevelopment. This study will also attempt to make connections to the extent to which these perceptions are impacted by interest grouping factors previously identified by researchers such as gender identity, race, sport played, scholarship money received, and level of competition. 


\section{CHAPTER II: LITERATURE REVIEW}

Because of the complex nature of identity, much research has been done to examine how varied components self-develop within an individual, particularly as it relates to one's own perceived societal context. Student-athletes' experiences within the social and societal constructs of sport necessarily craft their contextual identity as an athlete (Brewer, Van Raalte, \& Linder, 1993; C. Brown, Glastetter-Fender, \& Shelton, 2000; Lally, 2007). The risk associated with the crafting of any identity based on external factors can be the foreclosure of other aspects of self that will be necessary for healthy social function outside the context of one's primary interests, activities, and social groups (Good, Brewer, Petitpas, Van Raalte, \& Mahar, 1993; McQuown Linnemeyer \& Brown, 2010; Murphy, Petitpas, Brewer, \& others, 1996). Of particular concern in this exploratory study is identifying potential relationships between a student-athlete's identity, their perception of the role support services offered play in their development, and their indicated readiness to transition from collegiate sport performance to post-collegiate-athletic life.

\section{Social Identity Theory}

The notion that one's own self-concept is created and reinforced by the social groups to which they belong is at the core of Tajfel's Social Identity Theory (SIT) (Tajfel, 1981). Defined by Tajfel and Turner (1986), social identity is, at its most basic level, "those aspects of an individual's self-image that derive from the social categories to which he perceives himself as belonging" (p. 283). Due to the nature and demands of athletics - necessity of proximal time spent, reliance upon peers, and agreed-upon common goals - a link to formation of a common social bond away from competition is not difficult to imagine. It is relevant, then, to examine which aspects of this theory may inform the development of prescribed and common behaviors amongst certain segments of student-athletes. 
Hogg and Reid (2006) suggest that the type of social grouping that can occur amongst groups that unite around common goals with an added component of the desire to impress the group to which they belong produces a normative value structure, behavioral effect, and upheld image that "reflect a shared group prototype" (p. 18). This echoes the posit of Brown (2000) that, when viewed through the lens of SIT, determining factors for the actions of group members move beyond looking at stereotypes as distorted realities and into the notion that group perceptions can become blueprints for judgment and action. Media and entertainment can serve to reinforce these prescribed expectations and exacerbate outside stereotypes associated with groups, including student-athletes, through the aspects of that group they choose to highlight (Trepte, 2006).

There is a tendency, once one begins to identify with a particular social group and receives insider and outsider recognition of that belonging, to remain fixed in that mentality of membership, and adhere to its collective value system and actions, often without the perceived ability to seek a new social group (Tajfel \& Turner, 1986). This theory additionally draws on an assertion made by Marcia (1966) that ego-identity and self- and outside-validation of that identity can lead to a blurring or distortion of where self-asserted goals, behaviors, and mentalities end and those of their social validators begin.

\section{Athletic Identity and Identity Foreclosure}

Social identity theorists have explored athletic identity as a construct within Social Identity Theory with specific application to sport, due to the highly social nature of athletic preparation and performance. Brewer, Van Raalte and Linder (1993) defined the term athletic identity as the degree to which a person identifies with the role of an athlete and seeks outside acknowledgement of that role. Those who have a high athletic identity tend to be those who 
have achieved elite levels within athletics. The findings in this research, and that subsequently continued by Brewer and Cornelius (2001), enabled the researchers to conclude that elite athletes can show the tendency to craft identities strongly rooted in acquiring, possessing, and retaining the persona of "athlete." They subsequently developed the Athletic Identity Measurement Scale (AIMS), an instrument to rate the intensity of attachment to this label in individual athletes. Elite athletes tend to base their self-worth and self-esteem on their abilities, performance, and the appreciation of their athletic talent, while gradually neglecting other aspects of psycho-social development (Cieslak II, 2004). The concern inherent in such fierce attachment to athletic identity lies in the consequences for the person when the identifier of "athlete" is no longer applicable.

When faced with such difficult choices - in many cases, directly dictated by schedule, stigmas, pressures, and institutional or team culture - between serving sport as opposed to future career avenues, athletic identity can intensify to the extent that other elements of the development of self will be ignored (Good et al., 1993; Murphy et al., 1996). The resulting deficits have been attributed to what is called identity foreclosure in the literature. Good, Brewer, Petitpas, Van Raalte and Mahar (1993) summarize this concept as "a construct used to describe people who have committed to an occupation or an ideology without first engaging in exploratory behavior" (p. 2). This can lead to a perceived lack of need to make decisions based on anything other than one's primary identity. This process has been shown to be detrimental to career and other developmental maturity in research studies conducted in athletes, as well as in entertainment/performance-industry majors with similarly limited opportunities for lucrative professional careers (e.g. Good et al., 1993; McQuown Linnemeyer \& Brown, 2010; Murphy, Petitpas, Brewer, \& others, 1996; Whipple, 2009). 
This issue was recently explored by Kulics, Kornspan and Kretovics (2015), whose findings reinforced the supposition that high-stakes athletes may be inclined to take a short-term outlook rather than focusing on their post-sport careers. Their examination included decisions made regarding institution, collegiate major, course load, and eligibility maintenance, as well as probing the topic of "student-athlete friendly" majors (p. 4) and the benefits of the pursuit of them. The danger in this short-term-view approach to decision-making is the resultant difficulty or inability to adapt and transition to different phases of life and successfully navigate social pressures, familial and career demands, and situationally assimilative ability development.

Furthermore, the accompanying psycho-social consequences to these outcomes that result from individuals' inability to identify as anything other than an athlete can be incredibly isolating and lead to depression. International table tennis player and sport psychology student, Emma Vickers, had this to say about life post-athletics, "many will struggle with adapting to a 'regular life' where they are no longer in the limelight and perhaps in their eyes, become forgotten members of society" (Vickers, 2013). This posit from a high-stakes athlete is consistent with expert researchers on this topic. As Murphy, Petitpas, Brewer and others (1996) noted, "Failure to formulate mature career plans may account for some of the difficulties athletes encounter when faced with disengagement from sport roles" (p. 244).

\section{Personal Preparedness Post-Athletics}

Exacerbating the reluctance or inability to transition is the presence of various barriers including public, peer, institutional, and team pressures and other societal stigmas related to seeking mental, emotional, and even academic and career support services (Adams et al., 2015; López \& Levy, 2013; Mateos, Torregrosa, \& Cruz, 2010; Watson, 2006). Rising revenues, professional salaries, collegiate scholarships, and ascribed role-model status for athletes has led 
to cultural mandates for better behavior and arguments for athletes' exclusion from making circumstantial complaints (Ferrante, Etzel, \& Lantz, 1996). In this climate, an athlete's development as a person can be overlooked or ignored. This serves to further reinforce the vulnerability of athletes transitioning into post-elite-athletic life. In fact, Torre (2009) went so far as to label those who attain even professional athlete status as prey, and particularly susceptible of becoming those of whom to take advantage. This was noted in his Sports Illustrated article that famously posited that two years post-career, "78\% of former NFL players have gone bankrupt or are under financial stress because of joblessness or divorce and $60 \%$ of former NBA players are broke five-years post career" (p. 2). While these and any guesses at current numbers can be more speculative than scientific, the underlying reasons for these numbers cannot be ignored if society-at-large is to uphold the notion that participation in sport at any level can aid personal development in a well-rounded individual (Eime, Young, Harvey, Charity, \& Payne, 2013).

These statistics are especially interesting because the athletes included represent the two highest-grossing, traditional revenue sports in collegiate athletics. The gaps in research that exist related to these student-athletes' self-efficacy, perceptions and usage of available support services, and perceived preparedness need to be bridged. Student-athletes must have stigma-free access to preparatory services at amenable hours if they are to be prepared for sport at the next level, or transition to a career outside of athletic competition (e.g. Carodine, Almond, \& Gratto, 2001; Martens \& Lee, 1998; Watson, 2006). It will be especially imperative for the latter group. Collegiate student-athletes who will not compete professionally - the clear majority of NCAA competitors - who have spent their entire lives crafting an identity inextricably woven with sport will have no large payday to cushion their transition period. 
When student-athletes have devoted the vast majority of their time, effort, resources, and preparation at higher educational levels to sport, there is a danger that the healthy transition to a life without competitive athletics at its core will not occur (Lester, 2014). This research conducted by Lester, shared via the NCAA's Mind, Body and Sport Series, noted "many professional athletes have made no plans for their lives after their careers are over and when they are no longer in the spotlight." He further states the pain and long-term physical limitations, when added to the risk factors already discussed, can lead to serious depression and even suicidal thoughts and tendencies. Additionally, a different report from that same series used data collected about collegiate alcohol and drug abuse to suppose that high levels of depression and anxiety, to which student athletes are particularly susceptible, were significant risk factors for such abuse (Hainline, Beall, \& Wilfert, 2014). Those researchers also noted that "buying into the cultural myth" that this is normal on college campuses can also lead to decreases in academic success, increases in the risk of sexual assault and interpersonal violence.

Further confounding the personal development of these athletes is the inability to separate their identity "off the field" from their identity engaged in sport training and performance. As Brewer et al. (1993) note, this sort of exclusive athletic identity can make an individual prone to professional, social, and emotional pitfalls associated with identity foreclosure in other areas. Brewer and Cornelius (2001) assert that knowledge of any such tendencies in student-athletes can help service providers assess risk for maladjustment, and tailor interventions in response. Such deficits are specifically concerning when the career and decision-making processes that ease transition from elite sport participation are impeded by scheduling, outside stigma, and eligibility requirements (Adams et al., 2015; Grove, Lavallee, \& Gordon, 1997; López \& Levy, 2013; Murphy et al., 1996). 
A seeming cultural disconnect from this research base exists in practice within sport organizations and, particularly, collegiate institutions where students seem to be persuaded to serve their immediate athletic identity over any long-term goals. Most notably, this can occur when a student selects an academic major or course of study to pursue. Kulics and colleagues (2015) found a in a study of 1,027 collegiate student-athletes that a statistically significant number of them felt anxiety, stress and pressure to "choose the correct major" and, indeed, "felt trapped" by the "perceived inability to explore [other] majors" (p.9). Furthermore, they found $71 \%$ of male athletes and $64 \%$ of female athletes responded that not only were there college majors that favored student athletes, but they believed it was beneficial to enroll in these majors.

Another group of researchers recently opted to examine this concept further by surveying a group of 8,481 student-athletes from 164 NCAA member institutions. Rankin et al. (2016) chose to survey these students to get a clearer picture of the role this type of institutional climate plays in student-athlete decision-making. Consistent with their hypothesis, they found a correlation between the quality of the relationships forged with faculty and athletic personnel and academic success. The researchers then used these findings to encourage athletic departments to reach out to and make new connections with professionals within and outside the department who can help facilitate a more holistic approach to helping the student-athletes make wellrounded decisions with their future career plans and long-term goals as the primary motivating foci.

\section{NCAA Programming and Directives}

This conceptual approach will hopefully receive more traction and gain prevalence via the NCAA's new Life Skills program, which began last academic year. This program is “committed to the total development of student-athletes, preparing them with 'life skills' that are 
useful throughout the college experience and after graduation" (“Life Skills,” 2016). This program is based on one put into action by The Homer Rice Center for Sports Performance at Georgia Tech that includes: (1.) a Student Athlete Advisory Board (SAAB) to "evaluate programs and provide feedback"; (2.) a career development and placement initiative; (3.) the presentation of a series of topics relating to personal health and well-being; and (4.) facilitating community outreach projects ("The total person program," 2016).

There may be reason, though, to question the effectiveness of such a program on a wide scale based on the lack of success of a previous incarnation of a similar directive. "Life Skills" is part of the evolution the NCAA program called CHAMPS/Life Skills, which had similar directives and intent when it was introduced to the NCAA membership in 1994 (NCAA, 2008). It would seem that although directives and programs were established several years ago to promote personal and career development, there is still recent research to suggest there exists a reputation for practices that ignore and/or are antithetical to those ideals in athletic departments.

Banwell and Kerr (2016) chose to examine this phenomenon from the perspective of coaches. Admittedly, the interviews they conducted with their eight participants were all coaches at Canadian universities and thus are not members of the NCAA, but their answers to questions about their role in the development of student-athletes were telling of the view many coaches may have in the U.S. In general, the responses from interviewees indicated they were aware of the importance of the need to view their athletes as students and people first and embraced their roles in that sort of development, but there was a noted lack of specifics and an acknowledgement that many coaches do not have a formulated approach when it comes to building a strategic plan in that regard. 
This runs counter to the suggestion of researchers, such as Carodine, Almond, and Gratto (2001), who call for specific inventories of services used and reflection upon outcomes in order to better serve student-athletes as they transition to careers beyond collegiate sport. These researchers also cite the Division IA Athletic Directors Association's definition of a program of excellence being one that directly and explicitly involves career counseling, planning, and placement through student services.

\section{Need for Examination of Student-Athlete Perceptions}

While studies have been conducted to examine barriers preventing student-athletes from seeking support - particularly mental health - services, there is still a decided lack of updated research about student-athletes' perceptions of the services and how they are viewed and/or utilized as instruments to assist and facilitate their own development. A 2006 study noted that changing the perceived social stigma of an athlete seeking services demanded changes in service delivery (Watson, 2006). Yet, those same stigmas were cited by student-athletes in research conducted seven years later that additionally found some services are often unavailable during the times athletes are free to use them (López \& Levy, 2013). In that study, López and Levy conclude "the most pronounced barriers to counseling were related to lack of available time to seek services, along with the stigma of seeking help and perceiving oneself as weak" (p. 29). While this statement referenced mental health and counseling services, the implications of perceived weakness as a barrier to help-seeking behaviors is important to note as a potential factor in decisions regarding all supports.

The state of collegiate and professional sport, the evolving perception of the athlete in society, the proclivity of student-athlete disuse of offered services, and the cultural stigma toward utilizing those services makes the need for a better understanding of the student-athlete's 
perspective of their own capabilities to navigate life's challenges urgent. Furthermore, while many have examined the perceived transitional preparedness of college students in general and found there to be reason to assess and modify counsel and student support services accordingly (Bong, 2001; Taylor \& Betz, 1983; Zimmerman, 2000), there seems to be a significant gap in gathering appropriate data to do so in the relevant literature regarding student-athletes as the specific population.

Researchers have indicated that in order to assist in the development of specifically and strategically planned athlete-development programs (Banwell \& Kerr, 2016; Navarro, 2014), further study of the athlete's identity as it influences their perspective of services and transitional preparedness is needed (Kulics et al., 2015; López \& Levy, 2013; Rankin et al., 2016). As such, this study will examine the following questions:

(1a) What are student-athletes' perceptions of their own identity?

(1b) How do they perceive the support services they are offered?

(1c) How do they self-assess their satisfaction with their career preparedness?

(2) Are there differences between groups (divisional level of competition, scholarship status, gender identity, sport played, ethnic/racial identity, academic major, and academic year)?

(3) Is there a relationship between Athletic Identity scores, perception of support services, and situational career satisfaction scores? 


\section{CHAPTER III: METHOD}

This study utilized a cross-sectional survey research design via a combination of existing instruments with additional demographic and descriptive questions designed to group participants for comparative analysis. The instrument was utilized to measure responses from convenience samples of the population of NCAA Division I and III student-athletes. The researcher first sought and received human subject research approval from the Illinois State University Institutional Review Board (IRB).

\section{Participants}

\section{Population}

For the purposes of this study, the overall population was NCAA undergraduate studentathletes. Access to the population was limited by proximity and authorization to two samples of student-athletes from one Division III private university in the College Conference of Illinois and Wisconsin (CCIW) and one NCAA Division I-AA (FCS) public university in the Missouri Valley Conference (MVC). Although this was a sample of convenience, the sample was also purposeful because it was representative of cross-sections of the overall population from disparate ends of the competitive divisional spectrum, each with its own contrasting characteristics for comparative grouping purposes.

\section{Sample}

The researcher approached the Athletics department for each participating institution in the study for access. As prescribed by the IRB, access to student-athlete participants was facilitated by representatives within the participating institutions and survey instruments were emailed via this proxy relationship. Subsequent email reminders and follow-ups, as per the recommendations of Austin, Richter and Reinking (2008), assisted in the procurement of 248 
valid responses from the two institutions. Validity of responses was assessed by completion of pertinent components of the survey instrument. Not all responses included fully completed instruments, however completion of individual components within the greater structure of the instrument were considered valid for analysis. In those cases, inclusion of valid surveys was determined by full-completion of the section being analyzed.

Table 1

Participants by Grouping Factors

\begin{tabular}{lcc}
\hline & $n$ & \% of sample \\
\hline Division I & 114 & 46.0 \\
Division III & 127 & 51.2 \\
No Response & 7 & 2.8 \\
\hline Scholarshipped & 150 & 60.5 \\
Non-scholarshipped & 98 & 39.5 \\
\hline Male & 84 & 33.9 \\
Female & 148 & 59.7 \\
No Response & 16 & 6.5 \\
\hline Revenue Sport & 21 & 8.5 \\
Non-revenue Sport & 214 & 86.3 \\
No Response & 13 & 5.2 \\
\hline Sport-related Major & 36 & 14.5 \\
Non-sport-related Major & 212 & 85.5 \\
\hline Minority & 33 & 13.3 \\
White & 196 & 79.0 \\
No Response & 19 & 7.7 \\
\hline Freshman & 59 & 23.8 \\
Sophomore & 71 & 28.6 \\
Junior & 62 & 25.0 \\
Senior & 55 & 22.2 \\
\hline
\end{tabular}

\section{Institutional Service Profile}

Semi-structured, in-person interviews with athletic administrators with direct involvement in the addressing and administration of student-athlete support services were arranged and conducted to preliminarily gain situational perspective of responses from each institution involved in this study. The Division I institution had a far larger contingent of "in 
house" service coordinators and providers in every area assessed for perceived value. All support services had some sort of direct tie to the athletic department and staff members to assist in the "case-handling" of student-athletes. Conversely, the substantially smaller athletic department (though serving a higher student-athlete population) at the Division III institution had very few administrators and all support services were handled by the "outside" service providers available to the general campus population. While the DIII athletic department itself provided some workshop-style programming and opportunities to support and develop student-athletes "off-the-field," a much greater role for advising, recommending interventions and directing student-athletes to available support services was given to the coaches and teammates/peer group. In each case, the institutions provided some form of each support service assessed within this study.

\section{Instrument Development}

Because of the need for a larger amount of quantitative data to look for overall population trends, permission was sought and received to compile and adapt survey instruments from the work of Brewer, Van Raalte, and Linder (1993) and Sandstedt, Cox, Martens, Ward, Webber, and Ivey (2004) to collect data that provide a snapshot of current student-athlete perceptions. In addition to these existing instruments, demographic and other nominal items - designed to group student-athletes for comparative purposes - was created with assistance from other experts and included to measure perceptions and usage of support services offered. The compiled instrument was designed using Qualtrics creation and implementation software and it and all data were housed on a private, secure server affiliated with the program and the researcher's university. An online survey was selected to maximize ease of collection, data security, access to sample, and the scheduling constraints of the population of student athletes (Evans \& Mathur, 2005). To 
maximize amount of data collected and for subsequent future analysis of this collected data, basic demographic information items (to establish aforementioned grouping factors) followed the closed-ended and Likert-scale-based questions.

\section{Instrument Construction}

The instrument included questions from the "Athletic Identity Measurement Scale" (AIMS) utilized by Brewer and Van Raalte, and Linder (1993), which was already reviewed, piloted and shown to have a high reliability - Cronbach's alpha sample value of .93 with testretest value of .89 - and the "Student-Athlete Career Situation Inventory" (SACSI) which was also already reviewed, and found to have acceptable reliability for the total scale (.83) and for each individual factor: $.78, .80, .70, .72$, and .73 , respectively.

It should also be noted that although the SACSI instrument was revised to accommodate binary gender identity, and re-piloted by Cox, Sadberry, McGuire, and (2009) and shown to have acceptable average Cronbach's alpha sample-factor-values of .746 for males, and .798 for females, since factor groups/labels no longer remained the same, the original 30-item instrument was utilized to better facilitate comparison between groups.

Both instruments utilized have also been analyzed and found to be within acceptable value limits for validity measures. The AIMS instrument was tested for construct validity and after correlating it with other measures of similar construct, found it to be a valid measurement (Brewer et al., 1993). The researchers also found evidence of convergent and discriminant validity in the psychometric evaluation of the instrument. The AIMS instrument was later revised into the currently-included 7-item instrument by Brewer and Cornelius (2001) and this version was found to be valid using a confirmatory factor analysis. The original, 30-item, fivefactor SACSI was found to have internal consistency, and criterion-related validity via multiple 
regression analysis with an addendum regarding two of the factors (Sandstedt et al., 2004). The researchers also noted that, although certain factors accounted for small amounts of variance, each factor was conceptually warranted for analysis. This instrument also utilized Likert-based, closed-ended questions aimed to explore participant perceptions of student-athlete support services, self-reported usage of those services, GPA, and demographic questions. The amalgamated survey instrument was designed to analyze student perceptions of services offered, usage of those services, and measure any differences in resultant career preparedness.

\section{Content Validity}

The instrument was reviewed by other experts on this topic as a check for content validity. It was then distributed to a group of 15 former student-athletes for a face-validity analysis and adjustments were made where possible to ensure wording and survey flow were not confusing, and to streamline the instrument, which was then distributed to the sample. Internal reliability testing was conducted for the AIMS and individual SACSI factors using an exploratory factor analysis to calculate Cronbach's alpha (Yong \& Pearce, 2013). For the seven AIMS items, Cronbach's alpha was found to be .726 for the valid 245 respondents. SACSI factors 1-5 were found to have Cronbach's alpha values of .807, .787, .617, .829, and .699, respectively. While the alpha value for SACSI Factor 3, Locus of Control, may be considered questionable, for exploratory analysis purposes, significant findings were reported with the caveat that the reliability for that factor may limit the utility and/or applicability of any such finding.

\section{Independent Variables}

The first six independent variables included interest groups that have been shown to have marked differences in the above-mentioned research and were dummy-coded in the results 
section to compare the interest groups to the rest of the sample. These independent variables included:

\section{Division I Athlete (D1Ath)}

This interest group included those who competed at the NCAA Division I level.

\section{Scholarshipped Athlete (Schol)}

This interest group included student-athletes who received some form and percentage of scholarship money to attend school.

Male Athlete (Male)

This interest group differentiated by gender identity.

\section{Revenue Sport Athlete (RevSp)}

This interest group included the NCAA-defined revenue sport athletes - those who competed in football and men's basketball.

\section{Minority Athlete (Min)}

This interest group included non-white athletes.

\section{Athletes with Sport- and/or Recreation-Related Majors (SportMaj)}

This interest group included those student-athletes whose indicated academic major was specifically related to athletics, sport, recreation, or kinesiology. Health-related majors that were not specifically linked to sport (i.e. nursing, community health, etc.) were not included in this interest group.

The seventh independent variable was academic year (AcYear), a categorical variable with 5 potential levels, freshman to graduate student. For comparative purposes, the graduate category was omitted due to insufficient sample size. 
The final independent variable used for grouping was the continuous variable of grade point average (GPA). Values for this variable had a possible range of 0.00 to 4.00 .

\section{Dependent Variables}

\section{Athletic Identity (AI)}

The AIMS instrument that was included to measure Athletic Identity is a 7-Likert-scaleitem instrument using a rating scale with a range of 1-7. It was designed to produce a summative score. The higher the score, the higher level of Athletic Identity the respondent has.

\section{Perceptions of Support Services (PV)}

For consistency of scale, items in this section, created by the researcher, utilized a 1-7 Likert-scale design. Services were chosen based on NCAA suggested services and offerings from each institution and value ratings were self-contained for each service.

Academic support/tutoring services (PV1Acad) referred to one-on-one or small group, direct tutoring services via academic support centers. Study center services (PV2StudCen) referred to a central location with resources including computers, internet service, academic supports, and "drop-in” tutors available. Learning disability (PV3LDis) services were those institutionally-approved services afforded to those with a documented learning disability and functional limitations within educational settings. Mental health and wellness services (PV4MentHW) referred to support services for mental and emotional well-being and could include counseling, psychiatry, and psychological services. Personal and leadership development services (PV5PersLead) referred to athlete committees, forums, seminars, and mentorship to cultivate leadership skills. Community interaction and outreach services (PV6CommIO) referred to opportunities provided and created to make connections to unaffiliated organizations and people within the institution's community and surrounding areas 
for the purposes of development, donation, and service. Academic and career transition services (PV7Trans) referred to counseling services aimed at setting, evaluating, and developing goals beyond the undergraduate experience.

\section{SACSI Factors}

The SACSI (Sandstedt et al., 2004) itself was a 30-item, 1-5 scaled, Likert-based instrument comprised of questions to assess five distinct factors. Based on the factor loadings identified by Sandstedt et al., summative scores were produced for each of the five distinct factors. The higher the factor score, the stronger the respondent feels within the assertions of each factor area.

The first factor, Career Development Self-Efficacy (S1CarDev), measured selfconfidence in ability to "engage in career development tasks" (p. 90). Factor two, Career versus Sport Identity (S2CarVSport), measured the student-athlete's propensity to view him- or herself as a seeker of academic and career achievement over athletic achievement. Locus of Control (S3Locus), the third factor, measured the degree to which the student-athlete felt he or she had the autonomy to make his or her own decisions regarding personal career development (i.e. class registration choices, etc.). The fourth factor, Barriers to Career Development (S4Barriers), measured ability to transcend barriers to personal career development due to, for example, "lack of time, energy, accessibility of resources" (p. 91). Factor five, the Sport to Work Relationship factor (S5SportWork), measured the student-athlete's ability to recognize the applicability of skills "from their sport experience" (p. 91) to their future careers.

\section{Analysis of Data}

Given the quantitative nature of the collected data, the subsequent analyses performed were completed utilizing Statistical Package for the Social Sciences (SPSS) version 24.0.0.0. 
When attempting to understand the relationship between athletic identity, perception of available services, and transition/career preparedness, the first four research questions were used to provide a firmer base and explanatory support for findings and conclusions drawn for the final research question. Much of the data was descriptive in nature and utilized to create a crosssectional picture of the sample. Additionally, scores on instrument components of AIMS and SACSI, along with questions regarding service perceptions have been utilized to ascertain relationships present. It should be noted that, for all data sets and dependent variable results, outliers have been identified and removed utilizing quartile ranges as prescribed by Hoaglin, Iglewicz, and Tukey (1986). Additionally, sample sizes are included for all grouping factors, as some questions were omitted or declined by individual respondents. 


\section{CHAPTER IV: RESULTS}

This study was an effort to build on existing literature regarding strategically-planned student-athlete support and development programs (Banwell \& Kerr, 2016; Navarro, 2014), as well as provide a researcher-suggested, updated snapshot of student-athlete perceptions (Kulics et al., 2015; López \& Levy, 2013; Rankin et al., 2016). It investigated differences in studentathletes' perceptions of their own identity, available support services they are offered, and satisfaction with their career situation, as well as the relationship between those factors.

\section{Reliability}

AIMS and SACSI Factor scores were first tested for internal reliability within the sample. All responses were then analyzed for mean scores for AIMS, Perceived Value of Services, and SACSI Factor scores across all groups. Reliability for the AIMS instrument within this study was confirmed to be acceptable, with a Cronbach's alpha value of .726. Reliability for four of the five factors of the SACSI instrument within this study was confirmed to be within the consensus for acceptable for exploratory purposes, with Cronbach's alpha values (Peterson, 1994), while the Locus of Control measure, as mentioned above, may fall outside the acceptable limits and any results and/or conclusions drawn should be done with that in mind. See table 2. Table 2

\begin{tabular}{lccc} 
Reliability & Cronbach's Alpha & $\begin{array}{c}\text { Cronbach's Alpha Based on } \\
\text { Standardized Items }\end{array}$ & $N$ of Items \\
\hline AIMS & .726 & .737 & 7 \\
S1CarDev & .807 & .806 & 6 \\
S2CarVSport & .787 & .789 & 9 \\
S3Locus & .617 & .623 & 4 \\
S4Barriers & .829 & .832 & 6 \\
S5SportWork & .699 & .732 & 5 \\
\hline
\end{tabular}




\section{Athletic Identity, Perceptions of Supports, and Career Situation}

The first research question addressed descriptive statistics for athletic identity, perceived value of support services, and perception of career situation. Means, standard deviations, and ranges for each dependent variable are presented in Table 2.

\section{Athletic Identity}

The AIMS instrument produced a summative score from seven Likert-scale questions that were scaled with values of 1 (Strongly Disagree) to 7 (Strongly Agree). The athletic identity score was a sum of all AIMS factors; therefore, it was out of a possible 49 points. The mean athletic identity score in this study - all are varsity athletes - was very similar to the means in the Brewer and Cornelius (2001) study ( $M=37.96$ v. $M=38.21$, respectively). The standard deviation was more than 1.5 points lower $(S D=4.81$ v. $S D=6.54)$, which means there was less variability in athletic identity for this current sample of student athletes.

\section{Perceived Value of Support Services}

As described above, instrument-identified support services were included, grouped, and named based on NCAA directives and offerings from both included institutions. Each was rated on a Likert scale with values from 1 (Not Valuable) to 7 (Highly Valuable). Each rating was independently contained for each service. Due to the varied nature of the supports themselves, a summative score to mimic continuous data was not deemed appropriate. Nearly all services were assessed to be in the "moderately valuable" range. Academic support/tutoring $(M=4.91$, $S D=1.74)$, study center $(M=4.79, S D=1.87)$, mental health and wellness $(M=4.36, S D=$ 2.04), personal and leadership development $(M=4.21, S D=1.89)$, community interaction and outreach $(M=4.46, S D=1.94)$, and academic and career transition services $(M=4.77, S D=$ 1.83) all leaned toward positive perceptions of value, with academic support/tutoring services 
being viewed as most valuable, on average. The one exception was perceived value of learning disability services $(M=2.96, S D=2.10)$, with a less-than-moderate value-rating.

\section{Perceived Career Situation}

As previously described, the 30-item SACSI instrument provided summative scores for five different factors. Career Development Self-Efficacy $(M=23.74, S D=3.58)$, Career versus Sport Identity $(M=34.90, S D=5.40)$, Locus of Control $(M=15.44, S D=2.59)$, Barriers to Career Development $(M=18.82, S D=4.83)$, and Sport to Work Relationship $(M=20.51, S D=$ 2.88). These factors had maximum sum values of $30,45,20,30$, and 25 , respectively.

Table 3

Sample Size, Mean, Standard Deviation, and Range for the Dependent Variables

\begin{tabular}{lccccc}
\hline & $N$ & Mean & S.D. & Min & Max \\
\hline AIMS & 245 & 37.51 & 5.62 & 7 & 49 \\
PV1Acad & 240 & 4.91 & 1.74 & 1 & 7 \\
PV2StudCen & 240 & 4.79 & 1.87 & 1 & 7 \\
PV3LDis & 226 & 2.96 & 2.10 & 1 & 7 \\
PV4MentHW & 236 & 4.36 & 2.04 & 1 & 7 \\
PV5PersLead & 233 & 4.21 & 1.89 & 1 & 7 \\
PV6CommIO & 234 & 4.46 & 1.94 & 1 & 7 \\
PV7Trans & 230 & 4.77 & 1.83 & 1 & 7 \\
S1CarDev & 225 & 23.74 & 3.58 & 12 & 30 \\
S2CarVSport & 229 & 34.90 & 5.40 & 18 & 45 \\
S3Locus & 229 & 15.44 & 2.59 & 9 & 20 \\
S4Barriers & 228 & 18.82 & 4.83 & 6 & 30 \\
S5SportWork & 229 & 20.51 & 2.88 & 11 & 25 \\
\hline
\end{tabular}

\section{Differences in Identity and Perceptions}

The second research question investigated differences between interest groups for athletic identity, perceptions of support services, and perceived career situation. One-way ANOVAs were used to see if there were any differences in the three types of dependent variables - AIMS score, perceived value ratings, and individual SACSI factors - for any of the interest groups. Homogeneity of variances was not significant and the data met basic assumptions of an ANOVA 
once outliers were removed for AIMS and SACSI factors using the above mentioned interquartile outlier method (Hoaglin et al., 1986). For the GPA independent variable, simple linear regressions were conducted because both GPA and summative dependent variables of AIMS score and SACSI factors are continuous.

\section{Athletic Identity}

One-way ANOVAs were used to examine differences in athletic identity among the interest groups. Most compared groups did not have statistically significant athletic identity scores (see Table 3 ). Athletic division, $F(1,225)=0.66, p=.419$, gender, $F(1,222)=1.25, p=$ .265 , revenue sport status, $F(1,225)=1.62, p=.205$, athletic major, $F(1,237)=1.12, p=.292$, nor minority status, $F(1,220)=0.06, p=.804$, influence athletic identity. The analysis revealed only marginally significant differences for athletes with scholarships, $F(1,237)=3.32, p=.070$. Athletes with scholarships had, on average, athletic identity scores that were 1.15 points higher than athletes without scholarships. Marginal differences were also detected for students of different academic years, $F(3,234)=2.22, p=.087$. Results of Tukey HSD post hoc tests reveal the difference lies between students holding Freshman and Junior status $(p=.061)$. Freshmen, on average, report athletic identity scores that are 2.20 points higher than Juniors.

The final predictive relationship explored for athletic identity was the student athlete's GPA. A simple linear regression was calculated to predict athletic identity based on GPA. Results indicated GPA is significantly related to athletic identity, $F(1,234)=4.143, p=.043$, with an $\mathrm{R}^{2}$ of .017. The regression coefficient $(\beta)$ was -1.50 , which means for every point increase in GPA, athletic identity drops by 1.5 points. In other words, students with higher GPAs tended to have lower athletic identity. 
Table 4

Differences in Athletic Identity Scores Among Interest Groups

\begin{tabular}{lcc}
\hline & $n$ & $M(S . D)$. \\
\hline Division I & 110 & $38.15(4.57)$ \\
Division III & 123 & $37.64(5.04)$ \\
\hline Scholarshipped & 143 & $38.42(4.73)^{+}$ \\
Non-scholarshipped & 96 & $37.27(4.86)$ \\
\hline Male & 81 & $38.43(4.95)$ \\
Female & 143 & $37.68(4.79)$ \\
\hline Revenue Sport & 21 & $39.14(3.92)$ \\
Non-revenue Sport & 206 & $37.74(4.90)$ \\
\hline Sport-related Major & 34 & $38.76(5.12)$ \\
Non-sport-related Major & 205 & $37.82(4.75)$ \\
\hline Minority & 33 & $38.15(4.00)$ \\
White & 189 & $37.93(4.93)$ \\
\hline Freshman & 58 & $38.97(4.62)^{+}$ \\
Sophomore & 67 & $38.27(5.31)$ \\
Junior & 61 & $36.77(4.79)^{+}$ \\
Senior & 52 & $37.88(4.15)$ \\
\hline
\end{tabular}

${ }^{+} p<.10 ; * p<.05 ; * * p<.01 ; * * * p<.001$

\section{Perceived Value of Supports}

Next, differences among interest groups in student athlete ratings of support services

were explored. One-way ANOVAs were used to examine differences in perceived value factors among the interest groups. Most compared groups did not have statistically significant athletic identity scores (see Table 4). Significant influencers on each examined service's perceived value is outlined in the following paragraphs.

Academic Support/Tutoring Services. Scholarship status, $F(1,238)=1.43, p=.233$, gender, $F(1,228)=1.41, p=.237$, revenue sport competition, $F(1,226)=1.07, p=.303$, sportrelated major, $F(1,238)=2.54, p=.112$, nor minority status, $F(1,225)=2.58, p=.110$, influenced the perceived value of academic support/tutoring services (PV1Acad). The analysis revealed significant differences for athletes competing in Division I, $F(1,231)=4.71, p=.031$. Athletes in Division I valued these services, on average, .5 points higher than athletes competing 
in Division III. Significant differences were also detected for students of different academic years, $F(3,235)=3.80, p=.011$. Results of Tukey HSD post hoc tests revealed differences lie between students with Sophomore and Senior status $(p=.007)$. Sophomores, on average, reported perceived value scores for academic support and tutoring services that are 1 scale point higher than Seniors. A marginal difference was also detected between Juniors and Seniors $(p=$ .077). Juniors, on average, reported perceived value scores for academic support and tutoring services that are .7 scale points higher than Seniors.

Study Center Services. Revenue sport competition, $F(1,226)=.564, p=.453$, minority status, $F(1,225)=.270, p=.604$, nor academic year, $F(3,235)=1.104, p=.348$, influenced the perceived value of study center services (PV2StudCen). The analysis revealed significant differences for athletes competing in Division $\mathrm{I}, F(1,231)=57.67, p<.001$. Athletes in Division I valued these services, on average, 1.7 scale points higher than athletes competing in Division III. Significant differences were also detected for students of differing scholarship status, $F(1,238)=21.43, p<.001$. Scholarshipped athletes valued these services, on average, 1.1 scale points higher than non-scholarshipped athletes. Significant differences were additionally detected between genders, $F(1,228)=4.42, p=.037$. Male student-athletes valued these services, on average, .5 scale points lower than female student-athletes. Sport-related major status also produced significant differences, $F(1,238)=17.48, p<.001$. Student-athletes enrolled in a sport-related major valued these services, on average, 1.4 scale points higher than those with non-sport-related majors.

Learning Disability Services. Division of competition, $F(1,217)=.702, p=.403$, scholarship status, $F(1,224)=.814, p=.368$, gender, $F(1,214)=.492, p=.484$, competition in revenue sports, $F(1,212)=1.062, p=.304$, sport-related major status, $F(1,224)=2.499, p=$ 
.115 , nor academic year, $F(3,221)=1.277, p=.283$, influenced the perceived value of learning disability services (PV3LDis). The analysis revealed significant differences for minority athletes, $F(1,211)=17.452, p<.001$. Athletes who self-identified as minority valued these services, on average, 1.6 scale points higher than white athletes.

Mental Health and Wellness Services. Division of competition, $F(1,217)=.702, p=$ .403 , scholarship status, $F(1,224)=.814, p=.368$, competition in revenue sports, $F(1,212)=$ $1.062, p=.304$, sport-related major status, $F(1,224)=2.499, p=.115$, nor academic year, $F(3$, 221) $=1.277, p=.283$, influenced the perceived value of mental health and wellness services (PV4MentHW). The analysis produced marginally significant differences between genders, $F(1$, $224)=3.120, p=.079$. Male student-athletes, on average, valued these services .5 scale points lower than female student-athletes. Marginally significant differences were also detected in minority athletes, $F(1,221)=3.840, p=.051$. Athletes who self-identified as a minority valued these services, on average, 1.6 scale points higher than white athletes.

Personal or Leadership Development Services/Programs. No significant differences were discovered between interest groups regarding the perceived value of personal or leadership development services/programs (PV5PersLead). Division of competition, $F(1,224)=.262, p=$ .610 , scholarship status, $F(1,231)=.741, p=.390$, gender, $F(1,221)=.722, p=.397$, competition in revenue sports, $F(1,219)=.001, p=.980$, sport-related major status, $F(1,231)=$ $.787, p=.376$, minority status, $F(1,218)=1.349, p=.247$, nor academic year, $F(3,228)=.756$, $p=.520$, influenced the perceived value of these services.

Community Interaction and Outreach. Division of competition, $F(1,225)=.000, p=$ .994 , scholarship status, $F(1,232)=.119, p=.730$, competition in revenue sports, $F(1,220)=$ $.734, p=.392$, sport-related major status, $F(1,232)=.692, p=.406$, nor minority status, $F(1$, 
$219)=.135, p=.714$, influenced the perceived value of community interaction and outreach services (PV6CommIO). Significant differences were detected between genders, $F(1,222)=$ $4.705, p=.031$. Male student-athletes, on average, valued these services .6 scale points lower than female student-athletes. Marginally significant differences were also detected on the basis of academic year, $F(3,229)=2.238, p=.085$. Results of Tukey HSD post hoc tests reveal marginal differences lie between students with junior and senior status $(p=.098)$. Juniors, on average, reported perceived value scores for academic support and tutoring services that are .9 scale points higher than seniors.

Academic/Career Transition Advisement. No significant differences were discovered between interest groups regarding the perceived value of academic/career transition advisement services (PV7Trans). Division of competition, $F(1,221)=.1 .401, p=.238$, scholarship status, $F(1,228)=.268, p=.605$, gender, $F(1,218)=.001, p=.976$, competition in revenue sports, $F(1,216)=.533, p=.466$, sport-related major status, $F(1,228)=1.143, p=.286$, minority status, $F(1,215)=.041, p=.841$, nor academic year, $F(3,225)=.608, p=.610$, influenced the perceived value of these services.

GPA. The final predictive relationship explored for perceived values of service was the student athlete's GPA. Initial correlation results indicated GPA was not at all associated with any of the perceived value scores, so a regression analysis was deemed unnecessary. 
Table 5

Differences in Perceived Value of Supports Among Interest Groups

\begin{tabular}{|c|c|c|c|c|c|c|c|c|}
\hline & \multicolumn{2}{|c|}{ PV1Acad } & \multicolumn{2}{|c|}{ PV2StudCen } & \multicolumn{2}{|c|}{ PV3LDis } & \multicolumn{2}{|c|}{ PV4MentHW } \\
\hline & $n$ & $M(S D)$ & $n$ & $M(S D)$ & $n$ & $M(S D)$ & $n$ & $M(S D)$ \\
\hline D1 Athlete & 108 & $5.2(1.63)^{*}$ & 110 & $5.7(1.44)^{* * * *}$ & 102 & $2.8(2.08)$ & 105 & $4.5(2.06)$ \\
\hline D3 Athlete & 125 & $4.7(1.80)$ & 123 & $4.0(1.88)$ & 117 & $3.1(2.11)$ & 124 & $4.2(2.00)$ \\
\hline Schol & 145 & $5.0(1.74)$ & 147 & $5.2(1.74)^{* * * *}$ & 139 & $2.9(2.10)$ & 142 & $4.4(2.10)$ \\
\hline NonSchol & 95 & $4.8(1.73)$ & 93 & $4.1(1.88)$ & 87 & $3.1(2.10)$ & 142 & $4.4(2.10)$ \\
\hline Male & 84 & $4.8(1.74)$ & 84 & $4.5(1.88)^{*}$ & 82 & $3.1(2.10)$ & 83 & $4.1(2.06)^{+}$ \\
\hline Female & 146 & $5.0(1.71)$ & 146 & $5.0(1.82)$ & 134 & $2.9(2.11)$ & 143 & $4.6(2.01)$ \\
\hline RevSport & 20 & $5.3(1.69)$ & 20 & $5.1(2.08)$ & 20 & $3.5(2.21)$ & 20 & $4.3(2.56)$ \\
\hline NonRevSport & 208 & $4.9(1.74)$ & 208 & $4.9(1.74)$ & 194 & $2.9(2.08)$ & 204 & $4.4(1.98)$ \\
\hline SportMaj & 35 & $5.3(1.49)$ & 35 & $6.0(1.20)^{* * * *}$ & 33 & $2.4(1.87)$ & 33 & $4.6(2.18)$ \\
\hline NonSportMaj & 205 & $4.8(1.77)$ & 205 & $4.6(1.89)$ & 193 & $3.1(2.12)$ & 200 & $4.3(2.02)$ \\
\hline Min & 33 & $5.4(1.37)$ & 33 & $5.0(1.77)$ & 32 & $4.3(2.03)^{* * *}$ & 33 & $5.0(1.89)^{+}$ \\
\hline NonMin & 194 & $4.9(1.74)$ & 194 & $4.8(1.86)$ & 181 & $2.7(2.01)$ & 190 & $4.3(2.04)$ \\
\hline Freshman & 57 & $5.0(1.51)$ & 57 & $4.8(1.70)$ & 52 & $3.2(2.06)$ & 54 & $4.3(1.94)$ \\
\hline Sophomore & 68 & $5.3(1.79)^{* * *}$ & 69 & $5.0(1.85)$ & 63 & $3.1(2.27)$ & 67 & $4.7(2.14)$ \\
\hline Junior & 60 & $5.0(1.59)^{+}$ & 59 & $4.8(1.84)$ & 56 & $3.0(2.08)$ & 60 & $4.5(1.98)$ \\
\hline Senior & 54 & $4.3(1.92)^{+, * *}$ & 54 & $4.4(2.08)$ & 54 & $2.5(1.89)$ & 54 & $3.9(2.04)$ \\
\hline
\end{tabular}

\begin{tabular}{|c|c|c|c|c|c|c|}
\hline & \multicolumn{2}{|c|}{ PV5PersLead } & \multicolumn{2}{|c|}{ PV6CommIO } & \multicolumn{2}{|c|}{ PV7Trans } \\
\hline & $n$ & $M(S D)$ & $n$ & $M(S D)$ & $n$ & $M(S D)$ \\
\hline D1Ath & 105 & $4.3(1.94)$ & 106 & $4.5(1.93)$ & 102 & $4.6(1.85)$ \\
\hline D3Ath & 121 & $4.2(1.84)$ & 121 & $4.5(1.93)$ & 121 & $4.9(1.78)$ \\
\hline Scholarshipped & 142 & $4.3(1.95)$ & 143 & $4.5(2.00)$ & 139 & $4.8(1.89)$ \\
\hline Non-schol. & 91 & $4.1(1.80)$ & 91 & $4.4(1.85)$ & 91 & $4.7(1.74)$ \\
\hline Male & 84 & $4.1(1.81)$ & 84 & $4.1(1.97)^{*}$ & 83 & $4.8(1.78)$ \\
\hline Female & 139 & $4.3(1.93)$ & 140 & $4.7(1.87)$ & 137 & $4.8(1.83)$ \\
\hline Revenue Sport & 20 & $4.3(2.05)$ & 20 & $4.2(2.35)$ & 20 & $5.1(1.28)$ \\
\hline Non Rev & 201 & $4.2(1.86)$ & 202 & $4.5(1.87)$ & 198 & $4.7(1.84)$ \\
\hline Sport Major & 33 & $3.9(1.69)$ & 34 & $4.2(1.94)$ & 33 & $4.5(1.82)$ \\
\hline Non-sport & 200 & $4.3(1.92)$ & 200 & $4.5(1.94)$ & 197 & $4.8(1.83)$ \\
\hline Minority & 33 & $4.6(1.82)$ & 33 & $4.6(1.97)$ & 32 & $4.9(2.01)$ \\
\hline Non-minority & 187 & $4.2(1.88)$ & 188 & $4.5(1.90)$ & 185 & $4.8(1.77)$ \\
\hline Freshman & 54 & $4.2(1.79)$ & 55 & $4.3(1.84)$ & 53 & $4.6(1.78)$ \\
\hline Sophomore & 65 & $4.3(1.99)$ & 65 & $4.7(1.90)$ & 65 & $4.7(1.94)$ \\
\hline Junior & 59 & $4.4(1.81)$ & 60 & $4.8(1.82)^{+}$ & 58 & $5.1(1.71)$ \\
\hline Senior & 54 & $3.9(1.98)$ & 53 & $3.9(2.14)^{+}$ & 53 & $4.7(1.90)$ \\
\hline
\end{tabular}

${ }^{+} p<.10 ; * p<.05 ; * * p<.01 ; * * * p<.001$ 


\section{SACSI}

Finally, differences were explored among interest groups in student-athlete SACSI factor scores. One-way ANOVAs were used to examine differences in each of five SACSI factors Career Development Self-Efficacy (S1CarDev), Career versus Sport Identity (S2CarVSport), Locus of Control (S3Locus), Barriers to Career Development (S4Barriers), and Sport to Work Relationship (S5SportWork) - among the interest groups. Most compared groups did not have statistically significant athletic identity scores (see Table 5). Significant influencers on each examined SACSI factor are outlined in the following paragraphs.

Career Development Self-Efficacy. Division of competition, $F(1,217)=.202, p=$ .654 , scholarship status, $F(1,222)=.039, p=.844$, competition in revenue sports, $F(1,212)=$ $.379, p=.539$, minority status, $F(1,219)=1.015, p=.315$, nor academic year, $F(3,219)=.543$, $p=.653$, influenced the SACSI factor of career development self-efficacy (S1CarDev). The analysis produced significant differences between genders, $F(1,222)=4.391, p=.037$. Male student-athletes, on average, had a sum factor score 1.1 points lower than female studentathletes. Marginally significant differences were also detected in students enrolled in sportrelated academic majors, $F(1,222)=3.739, p=.054$. Athletes who are pursuing sport-related academic studies had a sum factor score, on average, 1.3 points higher than those studentathletes in other academic majors. Higher sum factor scores indicated higher levels of selfconfidence in the ability to engage in career development tasks.

Career Versus Sport Identity. Scholarship status, $F(1,222)=1.083, p=.299$, minority status, $F(1,219)=1.318, p=.252$, sport-related major status, $F(1,222)=.997, p=.319$, nor academic year, $F(3,219)=.369, p=.776$, influenced the SACSI factor of career versus sport identity (S2CarVSport). The analysis produced significant differences between Division I and 
Division III athletes, $F(1,218)=6.384, p=.012$. Division I student-athletes had a sum factor score of, on average, 1.7 points lower than Division III student-athletes. A significant difference was also found between genders, $F(1,222)=14.353, p<.001$. Male student-athletes, on average, had a sum factor score 2.5 points lower than female student-athletes. Competition in a revenue sport also proved to have significant effect on this factor $F(1,213)=4.165, p=.042$. Athletes who competed in football or men's basketball had a sum factor score, on average, 2.4 points lower than those who compete in other sports. Higher sum factor scores for this component indicated higher propensity for the student-athlete to view him- or herself as a seeker of academic and career achievement over athletic achievement.

Locus of Control. Division of competition, $F(1,222)=.371, p=.543$, scholarship status, $F(1,227)=.022, p=.883$, competition in revenue sports, $F(1,217)=1.438, p=.232$, sport-related major status, $F(1,227)=.085, p=.771$, minority status $F(1,224)=.440, p=.508$, nor academic year, $F(3,224)=.968, p=.409$, influenced the SACSI factor of locus of control (S3Locus). The analysis identified statistically significant differences between genders, $F(1$, $227)=16.013, p<.001$. Male student-athletes, on average, had a sum factor score 1.4 points lower than female student-athletes. Higher sum factor scores indicated the student-athlete feeling higher levels of autonomy to make his or her own decisions regarding personal career development (i.e. class registration choices, etc.).

Barriers to Career Development. Gender, $F(1,223)=1.046, p=.307$, competition in revenue sports, $F(1,213)=1.196, p=.275$, sport-related major status, $F(1,223)=.746, p=$ .389 , nor minority status, $F(1,220)=.258, p=.612$ influenced the SACSI factor of barriers to career development (S4Barriers). The analysis identified significant differences between NCAA division of competition, $F(1,218)=24.207, p<.001$. Division I student-athletes, on average, 
had a sum factor score 3 points lower than Division III student-athletes. Significant differences were also detected in scholarshipped athletes, $F(1,223)=5.393, p=.021$. Athletes who receive scholarship money had a sum factor score, on average, 1.5 points lower than those who do not. Significant differences were also detected between different academic years, $F(3,220)=3.191, p$ $=.025$. Results of Tukey HSD post hoc tests reveal significant differences lie between students with Freshman and Junior status $(p=.044)$. Freshmen, on average, had a sum factor score for this factor that is 2.4 points higher than Juniors. A significant difference was also shown to exist between Freshmen and Seniors $(p=.041)$. Freshmen, on average, had a sum factor score for this factor that is 2.5 points higher than Seniors. Higher sum factor scores indicated lower perceived hindrance to personal career development due to insufficient time, energy, and resources.

Sport to Work Relationship. Division of competition, $F(1,220)=.138, p=.711$, scholarship status, $F(1,225)=1.237, p=.267$, gender, $F(1,225)=.739, p=.391$, competition in revenue sports, $F(1,216)=1.217, p=.271$, minority status, $F(1,222)=.271, p=.603$, nor academic year, $F(3,223)=1.216, p=.305$, influenced the SACSI factor of sport to work relationship (S5SportWork). The analysis indicated significant differences due to enrollment in a sport-related major, $F(1,225)=4.989, p=.026$. Those pursuing sport-related majors, on average, had a sum factor score 1.2 points higher than those studying in other major areas. Higher sum factor scores indicated higher levels of student-athlete recognition of the applicability of skills gained from sport experiences to their future careers. 
Table 6

Differences in SACSI Factor Scores Among Interest Groups

\begin{tabular}{|c|c|c|c|c|c|c|}
\hline & \multicolumn{2}{|c|}{ S1CarDev } & \multicolumn{2}{|c|}{ S2CarVSport } & \multicolumn{2}{|c|}{ S3Locus } \\
\hline & $n$ & $M(S D)$ & $n$ & $M(S D)$ & $n$ & $M(S D)$ \\
\hline D1Ath & 100 & $23.9(3.41)$ & 99 & $34.3(4.86)^{*}$ & 103 & $15.6(2.42)$ \\
\hline D3Ath & 119 & $23.7(3.55)$ & 121 & $36.0(4.93)$ & 121 & $15.4(2.68)$ \\
\hline Schol & 133 & $23.8(3.56)$ & 132 & $35.0(4.93)$ & 137 & $15.4(2.43)$ \\
\hline NonSchol & 91 & $23.8(3.43)$ & 92 & $35.7(4.94)$ & 92 & $15.5(2.82)$ \\
\hline Male & 80 & $23.1(3.44)^{*}$ & 80 & $33.6(4.87)^{* * * *}$ & 82 & $14.5(2.70)^{* * * *}$ \\
\hline Female & 144 & $24.2(3.49)$ & 144 & $36.1(4.75)$ & 147 & $15.9(2.40)$ \\
\hline RevSp & 20 & $23.4(2.89)$ & 20 & $33.1(5.58)^{*}$ & 20 & $14.8(3.01)$ \\
\hline NonRevSp & 194 & $23.9(3.55)$ & 195 & $35.5(4.88)$ & 199 & $15.5(2.56)$ \\
\hline SportMaj & 30 & $24.9(2.79)^{+}$ & 31 & $34.4(4.99)$ & 32 & $15.3(2.29)$ \\
\hline NonSportMaj & 194 & $23.6(3.57)$ & 193 & $35.4(4.93)$ & 197 & $15.5(2.64)$ \\
\hline Min & 31 & $23.2(3.97)$ & 31 & $34.3(4.33)$ & 32 & $15.2(2.42)$ \\
\hline NonMin & 190 & $23.9(3.43)$ & 190 & $35.4(5.03)$ & 194 & $15.5(2.62)$ \\
\hline Freshman & 54 & $23.3(3.65)$ & 54 & $35.3(5.07)$ & 55 & $15.4(2.77)$ \\
\hline Sophomore & 62 & $23.8(3.59)$ & 64 & $34.9(4.46)$ & 65 & $15.3(2.40)$ \\
\hline Junior & 56 & $23.9(3.30)$ & 54 & $35.7(4.83)$ & 57 & $15.9(2.62)$ \\
\hline \multirow[t]{3}{*}{ Senior } & 51 & $24.1(3.48)$ & 51 & $35.0(5.50)$ & 51 & $15.1(2.59)$ \\
\hline & \multicolumn{2}{|c|}{ S4Barriers } & \multicolumn{2}{|c|}{ S5SportWork } & & \\
\hline & $n$ & $M(S D)$ & $n$ & $M(S D)$ & & \\
\hline D1Ath & 101 & $17.1(4.28)^{* * *}$ & 101 & $20.7(2.67)$ & & \\
\hline D3Ath & 119 & $20.1(4.68)$ & 121 & $20.6(2.87)$ & & \\
\hline Schol & 135 & $18.1(4.59)^{*}$ & 136 & $20.8(2.72)$ & & \\
\hline NonSchol & 90 & $19.6(4.72)$ & 91 & $20.3(2.83)$ & & \\
\hline Male & 82 & $19.1(4.38)$ & 81 & $20.8(2.74)$ & & \\
\hline Female & 143 & $18.4(4.85)$ & 146 & $20.5(2.79)$ & & \\
\hline RevSp & 20 & $17.6(4.79)$ & 20 & $21.3(2.12)$ & & \\
\hline NonRevSp & 195 & $18.8(4.59)$ & 198 & $20.5(2.82)$ & & \\
\hline SportMaj & 31 & $18.0(4.37)$ & 31 & $21.6(2.01)^{*}$ & & \\
\hline NonSportMaj & 194 & $18.8(4.74)$ & 196 & $20.4(2.84)$ & & \\
\hline Min & 32 & $19.1(3.38)$ & 31 & $20.4(2.82)$ & & \\
\hline NonMin & 190 & $18.6(4.89)$ & 193 & $20.6(2.74)$ & & \\
\hline Freshman & 53 & $20.2(4.41)^{*, *}$ & 54 & $20.4(2.63)$ & & \\
\hline Sophomore & 64 & $18.9(4.56)$ & 65 & $20.9(3.05)$ & & \\
\hline Junior & 57 & $17.8(4.69)^{*}$ & 57 & $20.1(2.83)$ & & \\
\hline Senior & 50 & $17.7(4.87)^{*}$ & 50 & $21.0(2.44)$ & & \\
\hline
\end{tabular}


GPA. A regression analysis was used to determine any relationship between studentathlete GPA and their SACSI scores. GPA was significantly related to the career development self-efficacy factor, $F(1,220)=11.877, p=.001$, with an $\mathrm{R}^{2}$ of .051 . The regression coefficient ( $\beta$ ) was 1.868 , which means on average, for every point increase in GPA, the SACSI score increased by 1.9 points, indicating higher levels of self-confidence in the ability to engage in career development tasks. Similarly, GPA was significantly related to the career versus sport identity factor, $F(1,220)=14.904, p=.000$. The $\mathrm{R}^{2}$ for this factor was .063 , and the regression coefficient $(\beta)$ was 2.913 , so as GPA increases by one point, career versus sport rating increases by an average of 2.9 points. Therefore, students with higher GPAs were more likely to view themselves as a seeker of academic/career achievement over athletic achievement. Finally, GPA was also significantly related to the third SACSI factor, locus of control, $F(1,225)=8.383, p=$ .004 . Explaining about $3.6 \%$ of this factor $\left(\mathrm{R}^{2}=.036\right)$, as GPA increased by one point, locus of control increased about 1.2 points $(\beta=1.156)$. Student-athletes with higher GPAs tended to believe they have more autonomy to make their own decisions regarding personal career development.

\section{Relationship Among Dependent Variables}

To discern if there were any relationships between the three dependent variables, Pearson correlations were conducted between AIMS scores, the seven perceived value scale scores, and the five SACSI factors. Perceived value scores for support services were all significantly and positively correlated with one another. This perhaps indicates response bias, but overall, if a respondent valued one support service, he/she tended to value all support services accordingly. Similarly, most SACSI factor sum scores were significantly, or moderately significantly, 
positively correlated, indicating that higher sum factor scores in any one factor typically meant higher sum factor scores in other areas. See Table 6 for the Pearson correlation values.

\section{Athletic Identity and PV of Supports}

Athletic identity was significantly correlated with three of the perceived value of support services scores and three of the SACSI scores. AIMS score was positively correlated with perception of academic support and tutoring service, study center services, and personal or leadership development services/programs $(r=.178, r=.157$, and $r=.163$ respectively). This means student athletes with higher athletic identity tended to value these services more.

\section{Athletic Identity and SACSI Factors}

Athletic identity was significantly correlated with three SACSI factor scores. AIMS score was significantly negatively correlated with Career vs Sport Development and Locus of Control $(r=-.276$, and $r=-.185$ respectively). This means student-athletes with higher athletic identity tended to view themselves as attending for the purposes of athletics with a lower sense of control over their own path. AIMS score had a significantly positive correlation with SACSI Factor 5, Sport to Work Relationship $(\mathrm{r}=.279)$. This means student-athletes with higher athletic identity tended to be able to view skills and experiences in athletics as translatable and applicable to their career development.

\section{SACSI Factors and PV of Supports}

Two SACSI factors were each found to be significantly positively correlated with three perceived value scores. Perceived valuations of personal or leadership development services/programs $(r=.132)$, community interaction and outreach services $(r=.132)$, and academic/career transition advisement services $(\mathrm{r}=.164)$ were positively correlated with SACSI Factor 2, career versus sport identity. This means the higher student-athletes valued those 
services, the higher their propensity to view themselves as seekers of academic and career achievement over athletic achievement. Perceived value scores for study center services ( $\mathrm{r}=$ .188), personal or leadership development services/programs $(\mathrm{r}=.191)$, and academic/career transition advisement services $(r=.233)$ were positively correlated with SACSI Factor 5, sport to work relationship. In other words, the higher student-athletes valued those services, the higher their perceived ability to view the skills and experiences gained in athletics as applicable to their future careers. 
Table 7

Pearson Correlations Between Dependent Variables

\begin{tabular}{|c|c|c|c|c|c|c|c|c|c|c|c|c|c|}
\hline Measure & 1 & 2 & 3 & 4 & 5 & 6 & 7 & 8 & 9 & 10 & 11 & 12 & 13 \\
\hline 1. Athletic ID & - & & & & & & & & & & & & \\
\hline 2. PV1Acad & $.178^{* *}$ & - & & & & & & & & & & & \\
\hline 3. PV2StudCen & $.157^{*}$ & $.591^{* * *}$ & - & & & & & & & & & & \\
\hline 4. PV3LDis & .080 & $.400^{* * * *}$ & $.276^{* * *}$ & - & & & & & & & & & \\
\hline 5. PV4MentHW & .070 & $.437^{* * * *}$ & $.355^{* * *}$ & $.561^{* * *}$ & - & & & & & & & & \\
\hline 6. PV5PersLead & $.163^{*}$ & $.381^{* * * *}$ & $.424^{* * * *}$ & $.430^{* * * *}$ & $.459^{* * * *}$ & - & & & & & & & \\
\hline 7. PV6CommIO & .087 & $.332^{* * * *}$ & $.335^{* * *}$ & $.357^{* * * *}$ & $.453^{* * * *}$ & $.701^{* * * *}$ & - & & & & & & \\
\hline 8. PV7Trans & $.159^{*}$ & $.263^{* * *}$ & $.257^{* * * *}$ & $.298^{* * * *}$ & $.312^{* * * *}$ & $.609^{* * * *}$ & $.623^{* * * *}$ & - & & & & & \\
\hline 9. S1CarDev & -.108 & .081 & $.111^{+}$ & -.065 & -.018 & .060 & .079 & .088 & - & & & & \\
\hline 10. S2CarVSport & $-.276^{* * *}$ & .092 & -.007 & -.036 & .047 & $.132^{*}$ & $.132^{*}$ & $.164^{*}$ & $.571^{* * * *}$ & - & & & \\
\hline 11. S3Locus & $-.185^{* *}$ & .051 & $.116^{+}$ & -.022 & .041 & .258 & .267 & .302 & $.467^{* * * *}$ & $.576^{* * *}$ & - & & \\
\hline 12. S4Barriers & .018 & .048 & .008 & .065 & .024 & .081 & .039 & .119 & $.290^{* * * *}$ & $.368^{* * *}$ & $.198^{* *}$ & - & \\
\hline 13. S5SportWork & $.279^{* * * *}$ & $.122^{+}$ & $.188^{* *}$ & -.038 & .021 & $.191^{* *}$ & .107 & $.233^{* *}$ & $.140 *$ & .050 & .015 & $.121^{+}$ & - \\
\hline
\end{tabular}

$+p<.1 ; * p<.05 ; * * p<.01 ; * * * p<.001$ 


\section{CHAPTER V: DISCUSSION}

The purpose of this exploratory study was, in part, to update previous research conducted to examine athletic identity (e.g. Brewer \& Cornelius, 2001; Brewer et al., 1993; Dee, 2014) and self-assessed career situation in student-athletes (e.g. Cox et al., 2009; Martens \& Lee, 1998; Sandstedt et al., 2004), but also to determine if previously identified interest groups still warrant further study and if certain factors are linked to one another (e.g. Andrassy, Svensson, Bruening, Huml, \& Chung, 2014; Navarro, 2014; Watson, 2006). When analyzing student-athlete identity as a subsidiary of social identity theory, it was important to examine these different groupings as each can perhaps provide contextual insights based upon interest group norms in subsequent studies. Finally, assessment of the perception of support services was included to follow up on the work of researchers examining barriers to service usage (e.g. Adams et al., 2015; López \& Levy, 2013; Watson, 2006).

\section{Athletic Identity}

An initial finding of note is that athletic identity is still a phenomenon worthy of exploration, despite some findings in this study that may indicate changes in its application to specific interest groups. The AIMS measure was found to have significant relationships with four of seven support service perceived value factors (Academic Support/Tutoring, Study Center, Personal Leadership, and Career/Transition), and three of five SACSI Factors (Career versus Sport, Locus of Control, and Sport to Work Relationship). Student-athletes with higher levels of athletic identity were found to value these support services significantly higher, while registering lower levels of autonomy and lowered recognition of themselves as enrolled for the purposes of career goals over athletic goals. While these differences may seem counter-intuitive at first, when viewed collectively, could be indicative that the higher a student-athlete's level of athletic 
identity, the more prone he/she is to see himself/herself as a sort of "fish out-of-water" in the world of higher education. This could explain the perceived need for academic and career supports to navigate the unfamiliar waters of academia en route to a productive career away from athletic competition.

\section{Differences Between Groups}

Interestingly, within athletic identity scores, only marginally significant differences $(p<$ .1) were found amongst any of the interest groups (scholarship status and academic year). This runs contrary to initial findings by Brewer and Cornelius (2001) when utilizing the updated, 7item instrument that was the basis for this portion of the current study. While mean AIMS scores for student-athletes as a population have not changed much from the 2001 sample, one particularly intriguing difference within the apparent homogenizing of athletic identity across traditional interest groups can be found in a substantial increase in Athletic Identity in female respondents. In that study, comparative analysis was reported by Brewer and Cornelius (2001) only for gender groups and for athletes vs. non-athletes. They found the mean AIMS score for males $(M=35.92, S D=8.59)$ and females $(M=30.15, S D=10.68)$ were significantly different. While those original numbers contain responses of non-athletes, making a direct comparison between studies difficult, the absence of significant differences between gender groups amongst student-athletes seems to indicate worthiness of further consideration and future exploration.

The growth in mean AIMS score and reduction in standard deviation or female athletes may be indicative of larger trends within the sport, broadcast, and social media industries. Since the initial study, there has been a rise of exposure to a wider range of sports and athletes via diversification of broadcast options (Hutchins \& Rowe, 2009). This, coupled with the advent of social media options that allow access to a wide range of individual, superstar athletes, including 
broader access to female athletes (Pegoraro, 2010), may contribute to a diversification of the athletic role model. This may have paved the way for all traditionally underrepresented interest groups - not only women - to find athletes to idolize who resonate more with their own values, interests, and demographics. Future research should attempt to discern what factors may be contributing to the homogenizing of athletic identity in elite-level athletes.

A final note of interest regarding grouping factors can be found in the significantly lowered athletic identity level found in juniors as compared to freshman. The mean athletic identity score was highest amongst freshman and lowest amongst juniors. This heightened level at the onset of a student-athlete's college career could be indicative of youth sports being a major contributing factor to increased athletic identity. Perhaps participation in youth sports at the highest levels - be it for school, club, or travel teams - predisposes younger athletes to higher levels of athletic identity before they even set foot on a college campus. Such a finding could be indicative of larger trends in sport development, youth participation, and coaching and potentially indicate the need for examination of younger populations when studying athletic identity and the potential benefits and risks associated.

\section{Divisional Level and the Relationship Between Identity, Valuation, and Transition Factors}

Although no significant difference was found in AIMS scores for DI student-athletes when compared to their DIII counterparts, significant differences in this interest group emerged in areas suggested and supported by previous research. These findings may warrant the consideration of a different approach to supporting these athletes by the institutions they attend. Division I student-athletes valued Academic Support/Tutoring and Study Center services significantly higher than their Division III counterparts. This is an interesting finding considering the Career Versus Sport Identity SACSI factor results indicate they are significantly 
less likely to view their primary purpose for attendance to be academic/career-based over athletically-based. Examination of the Barriers to Career Development SACSI Factor indicates they have a significant and substantially lower confidence in their ability to overcome barriers to career exploration. This might show evidence to support what Good et al. (1993) suggest, that an athlete with high AI can develop resistance to exploration of diverse education and career paths. Also, though, this could be indicative of the type of barriers caused by external expectations and pressures to conform to support network, peer, team, and institutional expectations, norms, and culture that have been noted in previous literature (Adams et al., 2015; López \& Levy, 2013; Martens \& Lee, 1998; Shurts \& Shoffner, 2004; Watson, 2006). While this finding has the potential to seem like a negative mark against Division I institutions, the juxtaposed high valuation of academic/tutoring and study center supports suggest these pressures are being addressed and mitigated in a "top-down fashion," with administrative directives as the driving force. This combination of significant differences could then be viewed through the above-mentioned "fish-out-of-water" lens as providing a bastion of institutionally-provided understanding and support within a setting student-athletes in this interest group tend to see as difficult to navigate, or perhaps, even as foreign territory.

\section{Perception of Support Service Value}

Another hidden success in this area may relate back to the overall positive perceived valuation of available student-athlete support services. This could indicate that the risk of previously identified potential institutional barriers such as heightened stigmas associated with seeking assistance or limited willingness for flexibility in delivery (Andrassy et al., 2014; Banwell \& Kerr, 2016; Horton, 2011; Rankin et al., 2016) are being mitigated to some extent by the participating institutions. The anomalous, lowered mean value score for learning disability 
services can, perhaps, be a result of disuse, unfamiliarity, or a low number of student-athletes with a diagnosed learning disability in the overall sample. The presence of an interest group minority student-athletes - whose valuation of that service was found to be significantly and meaningfully higher than the average would seem to support this assertion.

\section{Transition Factors Between Groups}

Significant differences for gender emerged within career situation factor scores. Though similar differences in AIMS scores and most perceived value ratings were notably absent, sum totals for the first three SACSI factors - career development self-efficacy, career versus sport identity and locus of control - indicated significant disparities. The data suggest male studentathletes are significantly less likely to confidently engage in career development tasks, more likely to view themselves as seekers of athletic success over academic/career success, and tend to feel less autonomy to direct their own paths through their education. Some of this disparity could be attributed to the presence of more numerous, lucrative, and significantly higher profile international and professional sport career opportunities for male student-athletes beyond college (Fink, 2015). However, regardless of the cause of these differences, their presence may indicate a need to specifically address the needs of male student-athletes differently regarding the direction and delivery of support services and the assessment of transitional readiness.

While the strongest correlations were found within self-contained instrument components, there is evidence to suggest that Athletic Identity, Valuation of Support Services, and Career/Transition preparedness are related and ought to be studied with the understanding of mutual influence. That said, only two SACSI factors, Career versus Sport Identity and Sport to Work Relationship, had multiple, significantly meaningful relationships to identity and service 
valuation and therefore should garner the bulk of research attention regarding athletic identity and service valuation.

\section{Institutional Recommendations}

Given the results of this exploratory study, institutions could seemingly benefit from knowing and utilizing these relationships to leverage instruments like the AIMS and SACSI to modify messages regarding support services and help develop a student-athlete's sense of purpose beyond their competitive sport. Given the brevity and ease of administration of the 7item AIMS instrument, it would seem to be the best place for institutions to begin, as it would require minimal time commitment, while providing the type of baseline that would be easily applied to simple, cost-effective interventions, as well as being easy to replicate for future benchmarking and analysis of growth. Service coordinators, advisors, coaches, and other stakeholders might be well served to administer these or similar instruments upon arrival to the institution to provide baseline measures and repeat the assessments annually to better track progress and utilize scores to encourage broadening of horizons, and tailor supports accordingly. This is not to say the end goal of any institution should be to reduce athletic identity. On the contrary, there seem to be positive correlations with valuations of supports and the ability to translate athletic development and skills to future careers. Athletic identity, therefore, should be looked at as a general indicator of tendencies to inform the creation of an individualized continuum of services and career trajectory. In an era during which analytics are being embraced more and more, having an analytical approach to supporting student-athletes outside of athletic competition makes sense for collegiate institutions. If support service coordinators can understand tendencies based on athletic identity levels in much the same way an offensive coordinator, for example, uses opposing personnel packages and subsequent tendencies to alter 
game plans, it can make for a similarly proactive approach to student-athlete development beyond the field of play.

An example of this type of proactive approach could be seen in the case of an incoming freshman who registers a high athletic identity. Knowing that an accompanying propensity to view oneself as primarily an athlete on campus might exist, appropriate interventions could be provided. This could come in the form of an academic or career counselor scheduling a session to explore interests and develop a trajectory for transitional success at a time when, as these results show, there are fewer barriers to career exploration.

Similarly, the knowledge of a significant, positive relationship between AIMS score and a perceived value of academic support and tutoring, study center, leadership, and transition services could help to target a student-athlete with information regarding access to them. A sort of "tailor-made" list of services and their availability and/or process for receiving each such correlated support could become a part of a departmental content-packet or an individual freshman consultation. This could be coupled with the already stated proactive approach to scheduling interventions to provide a stronger sense of belonging and connection to the areas academic and career development for student-athletes prone to the "fish-out-of-water" effect. In this regard, the role of coaches as well as teammates and peers to provide encouragement and a positive outlook regarding self-help-seeking behaviors cannot be understated. As such, a positive institutional culture toward holistic academic, socio-emotional, and transitional support of student-athletes should be fostered by administration via best practices including open dialogue about reducing stigmas, initiative-based seminars, and opportunities for connection to the community and others outside of the athletic department. 


\section{CHAPTER VI: LIMITATIONS AND FUTURE RESEARCH}

Due to the exploratory nature of this study, only significant and meaningful results were discussed. While significant differences were found amongst previously identified interest groups, many had negligible impacts on mean scores and ratings, and/or had such low response rates that any attempts to generalize findings to a larger population would be speculative at best. Considering this, it would seem all the examined interest groups continue to be valid subjects for future study.

A caveat that ought to be mentioned at the onset is the absence of a specific identity foreclosure measurement instrument. While the AIMS measures Athletic Identity and SACSI factor scores can be indicative of elements of foreclosure, a high AIMS score should not be considered to mean it is the only identity to which the respondents feel attachment. Studentathletes could also simultaneously have as fierce an attachment to other identities. Furthermore, while a high athletic identity score can tend to be mostly associated with negative factors, this study shows that there are positive associations as well, including increased valuation of support services and an increase in the perceived ability to translate athletic prowess and skill development to future career paths. Subsequently, although mentioned above, it should again be noted that the goal of support service providers should not simply be to lower athletic identity scores, but rather to view them as an informing factor for behavioral tendencies.

An additional proviso can be found in the decision to include a non-gendered SACSI instrument for the purposes of this study. The decision had been made by the original researchers to update the SACSI to provide differing instruments for male and female studentathletes, given the significant differences found across factors (Cox et al., 2009). These new, binary-gendered instruments do not, however, contain the same factors. Thus, for comparative 
purposes, it was deemed important to this study to include the original instrument, given parallel factor loadings. Future examinations that are less exploratory in nature could utilize the updated, gendered versions for potentially increased applicability of findings.

A major limitation in this study was the low response-rate from interest groups: minority $(n=33,13.3 \%)$ and revenue-sport $(n=21,8.5 \%)$ student-athletes, and those pursuing degrees in sport-related majors $(n=36,15.5 \%)$. While the NCAA does not publish statistics regarding sport-related major pursuit, it does provide demographic information and participation by sport. The latest NCAA and Racial and Gender Reports reveal participation in this study was not representative of overall athletic participation by minority athletes (female minority $=28.3 \%$, male minority $=36.3 \%$ ), nor was it representative of the percentage of revenue-sport studentathletes (18.4\%) within the overall population (Irick, 2017; Lapchick, 2018). As mentioned throughout, these groups have been found to be valid interest groups in past research and in this study, but meaningfully applicable generalizations for these populations must include a larger number of respondents. Future studies of this kind could focus on more targeted recruitment of participants in these interest groups.

Another limitation of this study was the sample including participants from only two institutions. Results, therefore, should not be generalized, though perhaps can be used to inform decision-making on similar groups in the future. An example of potential confounding factors is the differences seen between Division of NCAA competition could simply be the product of the types of services and climate/culture at these two institutions, rather than outcomes and results that can be expected to be seen unilaterally across all Division I and Division III institutions. Replication of this research including multiple institutions across all NCAA division levels is recommended in the future. Given these preliminary findings, perhaps a scaled version could 
include the collapsing of perceived value of individual services to categories such as academic, mental health, and transition services. Also, since transition is at the core of this research, perhaps focusing on the career versus sport and sport to work relationship factors would be beneficial. Collapsing the thirteen dependent variables in this study to six could not only provide a more manageable instrument, but perhaps also allow for greater institutional participation and student-athlete response rates. This could turn a more exploratory study into one that targets specific areas of interest with variables that have already been shown to be significant and allow for more in-depth analysis of relationships and differences between interest groups. The ability to articulate that specific purpose to gatekeepers at potential participating institutions could increase willingness to be included in such a study.

Additionally, when drawing conclusions regarding the reported perceived value of support services, caution should be used results of this study as they may indicate a response bias. Perceived value factors all showed significant and strong relationships to one another and have very similar descriptive values on the whole, which may indicate some internal pressure to value services that society-at-large views as valuable.

Career plan was not a factor in this study, but may be important to include in future studies, given that significant differences between academic years were found in the Barriers to Career Development SACSI factor. Perceived ability to overcome these barriers significantly decreased from freshmen to upperclassmen. This could indicate that as a student-athlete's career picture becomes clearer and more specific, his/her athletic schedules and regimens ultimately reduce career flexibility, direction, and choice (i.e. pursuit of internships and outside job opportunities). This could also be particularly applicable to those student-athletes whose courses of study require them to successfully complete an internship, practicum requirements, or engage 
in residencies for graduation. For example, teacher preparation programs, medical preparatory majors, and the like may be hindered because of participation in athletics. Consequently, future studies that include career plan as a moderator for examination of service valuation and/or transition may be a vital next step in assisting development of supports.

Ideally, future researchers may also want to look more in-depth at individual services and include utilization of those services as a factor, as well as probing for explanations for the assessed value. Because each support service is so different and the utility to each specific individual will likely vary greatly, this type of examination will be necessary to discern what truly impacts the use of these services. Additionally, many studies seem to assess barriers to service usage and career development, but few examine the effectiveness of these services within the population of student-athletes. Measures of effectiveness, including exit surveys of satisfaction, could be a useful tool in this area of support service evaluation.

Further examination of the "fish-out-of-water" effect is also warranted. That athletic identity is positively correlated with perceived value of academic, leadership, and transition services, yet negatively correlated with prioritization of career development and a sense of autonomy reveals an interesting dichotomy. Does a heightened athletic identity lead a studentathlete value support services more because of time constraints and traditionally identified barriers, or is the tendency to view oneself as an athlete first and foremost a trigger to seek the assistance of "academic natives" while in unfamiliar surroundings? Exploration of this phenomenon may require a more qualitative approach to research as socio-emotional factors, motivations, mindsets, and more specific career plans can be highly individualized.

Ultimately, the ideal goal of any such research in the future should be working toward identifying relationships between athletic identity, support services, and career factors with the 
long-term vision of the creation of a regression model to explain successful transition from collegiate sport to the workplace. 


\section{CHAPTER VII: CONCLUSION}

This study has contributed to the body of knowledge regarding athlete identity, perceptions of support, and readiness components surrounding transition from collegiate sport. Through the repetition of previously validated measures and updating these figures for the present, more insight has been provided in the quest to provide a bridge over this current gap in the literature and provide institutions of higher education, particularly those with elite-level student-athletes, with some research and recommendations to improve upon the delivery of support services aimed at fostering growth and preparedness for the future endeavors of those student-athletes. Previously identified interest groups, particularly those including gender and competition level, were found to have multiple significant differences in perceptions of services and career and transitional factors. Additionally, athletic identity was shown to have a significant relationship to multiple transitional factors that indicated a higher athletic identity is

linked to lowered transitional and career preparedness. These two findings give further credence to the necessity of evaluating this phenomenon and further studying its effects on studentathletes and the transition from sporting competition. 


\section{REFERENCES}

Adams, C., Coffee, P., \& Lavallee, D. (2015). Athletes' perceptions about the availability of social support during within-career transitions. Sport \& Exercise Psychology Review, 11(2), 37-48.

Andrassy, E. J., Svensson, P., Bruening, J., Huml, M. R., \& Chung, M. (2014). The role of organizational capacity in student-athlete development. Journal of Intercollegiate Sport, $7(2), 218-244$.

Austin, T. M., Richter, R. R., \& Reinking, M. F. (2008). A primer on web surveys. Journal of Allied Health, 37(3), 180-186.

Banwell, J., \& Kerr, G. (2016). Coaches' perspectives on their roles in facilitating the personal development of student-athletes. The Canadian Journal of Higher Education, 46(1), 1.

Bong, M. (2001). Role of self-efficacy and task-value in predicting college students' course performance and future enrollment intentions. Contemporary Educational Psychology, 26(4), 553-570. https://doi.org/10.1006/ceps.2000.1048

Brewer, B. W., \& Cornelius, A. E. (2001). Norms and factorial variance of the Athletic Identity Measurement Scale (AIMS). The Academic Athletic Journal, 15(2), 103-113.

Brewer, B. W., Van Raalte, J. L., \& Linder, D. E. (1993). Athletic identity: Hercules' muscle or Achilles' heel? International Journal of Sport Psychology, 24(2), 237-254.

Brown, C., Glastetter-Fender, C., \& Shelton, M. (2000). Psychosocial identity and career control in college student-athletes. Journal of Vocational Behavior, 56(1), 53-62. https://doi.org/10.1006/jvbe.1999.1691 
Brown, G. T., Goehlert, A., \& Seifert, C. (2014). Mind, body and sport: understanding and supporting student-athlete mental wellness. NCAA Publications. Retrieved from https://www.naspa.org/images/uploads/main/Mind_Body_and_Sport.pdf

Brown, R. (2000). Social identity theory: Past achievements, current problems and future challenges. European Journal of Social Psychology, 30, 745-778.

Carodine, K., Almond, K. F., \& Gratto, K. K. (2001). College student athlete success both in and out of the classroom. New Directions for Student Services, 2001(93), 19-33.

Cieslak II, T. J. (2004). Describing and measuring the athletic identity construct: Scale development and validation. The Ohio State University. Retrieved from https://etd.ohiolink.edu/!etd.send_file?accession=osu1091219903\&disposition=attachme nt

Corben, B. (2012, October 2). Broke. 30 for 30. ESPN.

Cox, R. H., Sadberry, S., McGuire, R. T., \& McBride, A. (2009). Predicting student athlete career situation awareness from college experiences. Journal of Clinical Sports Psychology, (3), 156-181.

Dee, T. S. (2014). Stereotype threat and the student-athlete. Economic Inquiry, 52(1), 173-182. https://doi.org/10.1111/ecin.12006

DiPaolo, D. G. (2017). Leadership education is not enough: Advancing an integrated model of student-athlete development. Journal of Leadership Education, 16(1). Retrieved from http://journalofleadershiped.org/attachments/article/486/0577_diPaolo.pdf

Eime, R. M., Young, J. A., Harvey, J. T., Charity, M. J., \& Payne, W. R. (2013). A systematic review of the psychological and social benefits of participation in sport for children and 
adolescents: Informing development of a conceptual model of health through sport. International Journal of Behavioral Nutrition and Physical Activity, 10(1), 98.

Evans, J. R., \& Mathur, A. (2005). The value of online surveys. Internet Research, 15(2), 195219. https://doi.org/10.1108/10662240510590360

Fink, J. S. (2015). Female athletes, women's sport, and the sport media commercial complex: Have we really “come a long way, baby”? Sport Management Review, 18(3), 331-342. https://doi.org/10.1016/j.smr.2014.05.001

Gaines, C. (2016, October 14). The difference in how much money schools make off of college sports is jarring, and it is the biggest obstacle to paying athletes. Retrieved October 23, 2017, from http://www.businessinsider.com/ncaa-schools-college-sports-revenue-201610

Good, A. J., Brewer, B. W., Petitpas, A. J., Van Raalte, J. L., \& Mahar, M. T. (1993). Identity foreclosure, athletic identity, and college sport participation. The Academic Athletic Journal, 1-11.

Grove, J. R., Lavallee, D., \& Gordon, S. (1997). Coping with retirement from sport: The influence of athletic identity. Journal of Applied Sport Psychology, 9(2), 191-203.

Hainline, B., Beall, L., \& Wilfert, M. (2014, November 4). Mind, body and sport: Substance use and abuse [Text]. Retrieved November 13, 2016, from http://www.ncaa.org/health-andsafety/sport-science-institute/mind-body-and-sport-substance-use-and-abuse

Hayes, M. (2017, August 8). Josh Rosen q\&a: UCLA QB on injuries, NCAA and post-NFL goal to "own the world." Retrieved October 23, 2017, from http://bleacherreport.com/articles/2722587-josh-rosen-qa-ucla-qb-on-injuries-ncaa-andpost-nfl-goal-to-own-the-world 
Hoaglin, D. C., Iglewicz, B., \& Tukey, J. W. (1986). Performance of some resistant rules for outlier labeling. Journal of the American Statistical Association, 81(396), 991. https://doi.org/10.2307/2289073

Hogg, M. A., \& Reid, S. A. (2006). Social identity, self-categorization, and the communication of group norms. Communication Theory, 16(1), 7-30. https://doi.org/10.1111/j.14682885.2006.00003.x

Horton, D. (2011). Developing an institutional culture toward degree attainment for student athletes. New Directions for Community Colleges, 2011(155), 27-33. https://doi.org/10.1002/cc.455

Hutchins, B., \& Rowe, D. (2009). From broadcast scarcity to digital plenitude: The changing dynamics of the media sport content economy. Television \& New Media, 10(4), 354-370. https://doi.org/10.1177/1527476409334016

Irick, E. (2017). 2016-17 NCAA sports sponsorship and participation rates report (pp. 1-305). Indianapolis: National Collegiate Athletic Association. Retrieved from http://www.ncaa.org/sites/default/files/2016-17NCAA-0472_ParticRatesReportFINAL_20171120.pdf

Kulics, J. M., Kornspan, A. S., \& Kretovics, M. (2015). An analysis of the academic behaviors and beliefs of Division I student-athletes: The impact of the increased percentage toward degree requirements. College Student Journal, 49(1), 1-12.

Lally, P. (2007). Identity and athletic retirement: A prospective study. Psychology of Sport and Exercise, 8(1), 85-99. https://doi.org/10.1016/j.psychsport.2006.03.003 
Lapchick, R. E. (2018). The 2017 racial and gender report card: College sport (pp. 1-89). University of Central Florida: Institute for Diversity and Ethics in Sport. Retrieved from http://nebula.wsimg.com/5665825afd75728dc0c45b52ae6c412d

Lester, D. (2014, November 5). Mind, body and sport: Suicidal tendencies [Text]. Retrieved November 8, 2016, from http://www.ncaa.org/health-and-safety/sport-scienceinstitute/mind-body-and-sport-suicidal-tendencies

Life Skills. (2016). [Text]. Retrieved November 14, 2016, from http://www.ncaa.org/about/resources/leadership-development/life-skills

López, R. L., \& Levy, J. J. (2013). Student athletes' perceived barriers to and preferences for seeking counseling. Journal of College Counseling, 16(1), 19-31. https://doi.org/10.1002/j.2161-1882.2013.00024.x

Marcia, J. E. (1966). Development and validation of ego-identity status. Journal of Personality and Social Psychology, 3(5), 551.

Martens, M. P., \& Cox, R. H. (2000). Career development in college varsity athletes. Journal of College Student Development, 41, 123-134.

Martens, M. P., \& Lee, F. K. (1998). Promoting life-career development in the student athlete: How can career centers help? Journal of Career Development, 25(2), 123-134.

Mateos, M., Torregrosa, M., \& Cruz, J. (2010). Evaluation of a career assistance programme for elite athletes: Satisfaction levels and exploration of career decision making and athleticidentity. Kinesiologia Slovenica, 16. Retrieved from http://www.fsp.unilj.si/mma_bin.php?id=20110318104519 
McQuown Linnemeyer, R., \& Brown, C. (2010). Career maturity and foreclosure in student athletes, fine arts students, and general college students. Journal of Career Development, 37(3), 616-634. https://doi.org/10.1177/0894845309357049

Murphy, G. M., Petitpas, A. J., Brewer, B. W., \& others. (1996). Identity foreclosure, athletic identity, and career maturity in intercollegiate athletes. Sport Psychologist, 10, 239-246.

Navarro, K. M. (2014). A conceptual model of Division I student-athletes' career construction processes. College Student Affairs Journal, 32(1), 219.

Osborne, B. (2014). The myth of the exploited student-athlete. Journal of Intercollegiate Sport, 7(2), 143-152. https://doi.org/10.1123/jis.2014-0136

Pegoraro, A. (2010). Look who's talking — athletes on Twitter: A case study. International Journal of Sport Communication, 3(4), 501-514. https://doi.org/10.1123/ijsc.3.4.501

Peterson, R. A. (1994). A meta-analysis of Cronbach's coefficient alpha. Journal of Consumer Research, 21(2), 381. https://doi.org/10.1086/209405

Powell, R. (2017, March 10). Estimated probability of competing in professional athletics [Text]. Retrieved March 19, 2018, from http://www.ncaa.org/about/resources/research/estimated-probability-competingprofessional-athletics

Rankin, S., Merson, D., Garvey, J. C., Sorgen, C. H., Loya, K., \& Oseguera, L. (2016). The influence of climate on the academic and athletic success of student-athletes: Results from a multi-institutional national study. The Journal of Higher Education, 87(5), 701730. 
Sandstedt, S. D., Cox, R. H., Martens, M. P., Ward, D. G., Webber, S. N., \& Ivey, S. (2004). Development of the student-athlete career situation inventory (SACSI). Journal of Career Development, 31(2), 79-93.

Schoen, J. W. (2015, June 16). Why college costs are so high and rising. Retrieved October 23, 2017, from https://www.cnbc.com/2015/06/16/why-college-costs-are-so-high-andrising.html

Shurts, W. M., \& Shoffner, M. F. (2004). Providing career counseling for collegiate studentathletes: A learning theory approach. Journal of Career Development, 31(2), 95-109.

Tajfel, H. (1981). Human groups and social categories: Studies in social psychology. CUP Archive.

Tajfel, H., \& Turner, J. C. (1986). The social identity theory of intergroup behavior. In S. Worchel \& W. G. Austin (Eds.), Psychology of intergroup relations (2nd ed., pp. 7-24). Chicago, IL: Nelson-Hall.

Taylor, K. M., \& Betz, N. E. (1983). Applications of self-efficacy theory to the understanding and treatment of career indecision. Journal of Vocational Behavior, 22(1), 63-81.

The total person program. (2016). Retrieved November 14, 2016, from http://www.ramblinwreck.com/school-bio/geot-rice-total.html

Torre, P. S. (2009, March 23). How (and why) athletes go broke. Sports Illustrated. Retrieved from http://www.si.com/vault/2009/03/23/105789480/how-and-why-athletes-go-broke

Trepte, S. (2006). Social identity theory. In J. Bryant \& P. Vorderer (Eds.), Psychology of Entertainment. Mahwah, NJ: Lawrence Erlbaum Associates Publishers. 
Vickers, E. (2013). Life after sport: Depression in the retired athlete. Retrieved November 13, 2016, from http://believeperform.com/wellbeing/life-after-sport-depression-in-retiredathletes/

Watson, J. C. (2006). Student-athletes and counseling: Factors influencing the decision to seek counseling services. College Student Journal, 40(1), 35.

Whipple, K. R. (2009). Athletic identity, identity foreclosure, and career maturity: An investigation of intercollegiate student-athletes. Iowa State University. Retrieved from http://search.proquest.com/openview/a2648dcc69b9601f3e1c0d1b73e8a1bc/1 ?pqorigsite $=$ gscholar $\& \mathrm{cbl}=18750 \&$ diss $=\mathrm{y}$

Wilson, R. (2017, May 7). Look: Cardale Jones, who once said, “we ain’t come here to play school," graduates. Retrieved October 23, 2017, from https://www.cbssports.com/nfl/news/look-cardale-jones-who-once-said-we-aint-comehere-to-play-school-graduates/

Yong, A. G., \& Pearce, S. (2013). A beginner's guide to factor analysis: Focusing on exploratory factor analysis. Tutorials in Quantitative Methods for Psychology, 9(2), 79-94.

Zimmerman, B. J. (2000). Self-efficacy: An essential motive to learn. Contemporary Educational Psychology, 25(1), 82-91. https://doi.org/10.1006/ceps.1999.1016 
APPENDIX A: SURVEY INSTRUMENT

\section{Athletic Identity, Service Usage, and Transition}

Information about Being in a Research Study

Illinois State University

Athletic identity, institutional support services, and transition: An analysis of studentathlete perceptions

\section{Description of the Study and Your Part in It}

John Kaczorowski and Dr. Rebecca Achen from Illinois State University invite you to take part in a research study. The purpose of this study is to explore relationships between athletic identity, the use of student-athlete support services, and post-athletic transition preparedness.

Because you are an intercollegiate student-athlete, your athletic department was asked and agreed to send this survey to you and you are being asked to click on the anonymous survey link and complete the survey. Your time commitment will be approximately 5-10 minutes.

\section{Risks and Discomforts}

If you choose to participate, you may experience minimal inconvenience in taking the survey, as participation will temporarily remove you from your normal day-to-day activities. As with most studies, there is a risk of loss of confidentiality. You may feel slight psychological discomfort when completing the survey.

\section{Possible Benefits}

There are no direct benefits to you, the participant, in this study. However, findings and suggestions to improve support service delivery will be shared with institutions to better assist student-athletes in the future.

\section{Protection of Privacy and Confidentiality}

Special care will be taken in maintaining the confidentiality of the participants during all stages 
of the research project. We will do everything we can to protect your privacy and confidentiality. Only the researchers will have access to your survey responses, and no personal identifying information will be collected.

\section{Choosing to Be in the Study}

Participants must be 18 years of age or older to participate in this study. You do not have to be in this study. You may choose not to take part and you may choose to stop taking part at any time. You will not be punished in any way if you decide not to be in the study or to stop taking part in the study. Your responses will be kept confidential and your participation is completely voluntary. There are no right or wrong answers to any survey questions and you may withdraw from the study at any time without penalty.

If you choose to stop taking part in this study, the information you have already provided will be used in a confidential manner or will be destroyed immediately, as you choose.

\section{Contact Information}

If you have any questions or concerns about this study or if any problems arise, please contact

Dr. Rebecca Achen at Illinois State University at 309-438-8557.

If you have any questions or concerns about your rights in this research study please contact the Illinois State University Research Ethics and Compliance Office at 309-438-2529 or rec@ilstu.edu.

\section{Consent}

\section{By clicking next, I agree to take part in this study.} If you do not agree to participate in the study, please close your browser now. 
Q1 In which intercollegiate sport(s) do you participate?

Q2 In which level of NCAA competition do you participate?

FBS - Division I

FCS - Division I

Division I (Non-Football)

Division II

Division III

Q3 What is your current academic year?

Freshman

Sophomore

Junior

Senior

Fifth-Year Senior

Graduate Student

Prefer not to answer

Q4 What is your academic major?

Q5 What is your estimated current GPA (4.0 Scale)? 
Q6 These questions are designed to measure people's perceptions about their athletic role. There are no right or wrong answers. Use the scale below to respond to each statement.

\begin{tabular}{|c|c|c|c|c|c|c|c|}
\hline & $\begin{array}{l}\text { Strongly } \\
\text { Disagree }\end{array}$ & Disagree & $\begin{array}{l}\text { Moderately } \\
\text { Disagree }\end{array}$ & Unsure & $\begin{array}{l}\text { Moderately } \\
\text { Agree }\end{array}$ & Agree & $\begin{array}{c}\text { Strongly } \\
\text { Agree }\end{array}$ \\
\hline $\begin{array}{l}\text { 1) I consider } \\
\text { myself an } \\
\text { athlete. }\end{array}$ & 0 & 0 & $\bigcirc$ & 0 & O & 0 & $\bigcirc$ \\
\hline $\begin{array}{l}\text { 2) I have } \\
\text { many goals } \\
\text { related to } \\
\text { sports. }\end{array}$ & 0 & 0 & 0 & 0 & O & $\bigcirc$ & $\bigcirc$ \\
\hline $\begin{array}{l}\text { 3) Most of my } \\
\text { friends are } \\
\text { athletes. }\end{array}$ & 0 & 0 & 0 & O & $\bigcirc$ & 0 & 0 \\
\hline $\begin{array}{l}\text { 4) Sport is the } \\
\text { most } \\
\text { important } \\
\text { part of my } \\
\text { life. }\end{array}$ & 0 & 0 & 0 & 0 & $\bigcirc$ & $\bigcirc$ & $\bigcirc$ \\
\hline $\begin{array}{l}\text { 5) I spend } \\
\text { more time } \\
\text { thinking } \\
\text { about sport } \\
\text { than } \\
\text { anything } \\
\text { else. }\end{array}$ & 0 & 0 & 0 & 0 & O & $\bigcirc$ & 0 \\
\hline $\begin{array}{l}\text { 6) I feel bad } \\
\text { about } \\
\text { myself } \\
\text { when I do } \\
\text { poorly in } \\
\text { sport. }\end{array}$ & ○ & 0 & 0 & $\bigcirc$ & $\bigcirc$ & 0 & 0 \\
\hline $\begin{array}{l}\text { 7) I would be } \\
\text { very } \\
\text { depressed if } \\
\text { were } \\
\text { injured and } \\
\text { could not } \\
\text { compete in } \\
\text { sport. }\end{array}$ & ○ & $\bigcirc$ & ○ & 0 & 0 & $\bigcirc$ & O \\
\hline
\end{tabular}


Q7 I receive scholarship money.
Yes
No

\section{Skip To: $Q 10$ If I receive scholarship money. $=$ No}

Q8 At what percentage of expense?
$25 \%$ or less
$26 \%-50 \%$
$51 \%-75 \%$
$76 \%-99 \%$
Full

Q9 What is the basis/reason for this scholarship?
Academic
Athletic
Leadership
Other 
Q10 I have utilized institution provided support services (ex. academic support, mental health services, etc).

Yes

No

Skip To: Q13 If I have utilized institution provided support services (ex. academic support, mental health servic... = No

Q11 Select all school-provided support services you have utilized.

Academic Support/Tutoring

Study Center Services

Learning Disability Services

Mental Health and Wellness Services

Personal or Leadership Development Services/Programs

Community Interaction and Outreach Services/Programs

Academic/Career Transition Advisement Services 
Q12 About how many hours total (on average) do you spend utilizing these services per week?

Q13 Are you required to use any of these services?

Yes

No

Skip To: Q15 If Are you required to use any of these services? = No

Q14 Which school-provided support services are you required to utilize?

Academic Support/Tutoring

Study Center Services

Learning Disability Services

Mental Health and Wellness Services

Personal or Leadership Development Services/Programs

Community Interaction and Outreach Services/Programs

Academic/Career Transition Advisement Services 
Q15 Based on your experiences with or perceptions of the following services, use the scale below to rate how valuable each service is to you personally.

Not

Valuable

(1)

(2)

(3)

Moderately

Valuable

(4)

(5)

(6)

Highly

Valuable

(7)

Academic
Support/Tutoring
Study Center
Services
Learning
Disability
Services
Mental Health and
Wellness Services
Personal or
Leadership
Development
Services/Programs
Community
Interaction and
Outreach
Services/Programs
Academic/Career
Transition
Advisement
Services

Academic

Support/Tutoring

Study Center

Services

Learning

Disability

Services

Mental Health and

Wellness Services

Personal or

Leadership

Development

Community

Interaction and

Outreach

Services

(1)

○

(1)

$\bigcirc$

$\bigcirc$

$\bigcirc$

$\bigcirc$

$\bigcirc$

$\bigcirc$


Q16 Please select the choice that corresponds with the extent to which you agree or disagree with Strongly Disagree Disagree Neutral Agree Strongly each item.

1) I do not have enough time to explore potential career opportunities.

2) I have enough careerrelated information to make informed decisions about potential careers.

3) I am confident about my ability to find a satisfactory career.

4) My athletic involvement limits me from exploring potential careers until my season is over.

5) I have a good understanding of the steps I need to take to find a satisfactory career.

6) I have a strong interest in at least one potential career.

7) I am often too tired to explore my career interests.

8) I would be willing to explore the university's career center. 
9) Excelling in academics is as important to me as excelling in my sport.

10) I am an athlete first, student second.

11) Many job-related skills can be learned from experiences in sport.

12) I have many personal goals outside of sport.

13) It is difficult for me to think about careers because I am an athlete.

14) I believe that being an athlete makes me more suitable for certain careers.

15) My main reason for being at this university is to participate in my sport.

16) My commitments as an athlete do not hinder me from exploring potential career opportunities.

17) The time I have spent being an athlete has kept me from doing other things that might help me explore possible careers.

18) Being an athlete has helped me develop skills that will help me be successful in my desired career. 
19) Being an athlete has influenced my thinking about what I might want to do for a career.

20) In choosing a major, I am more concerned about what is easiest to manage with my athletic commitment than about what really interests me.

21) Most of the academic decisions I make are strongly influenced by what others may suggest.

22) Being a professional athlete is the only career that interests me.

23) I have a good sense of what interests me academically.

24) I am more concerned with just graduating, rather than the field in which I actually get my degree in.

25) I am happy with my current major.

26) I feel pressure from others to pursue a particular career.

27) I am pursuing a certain career only because others have told me I would be good at it. 
28) I am focusing more on preparing for a career than on becoming a professional athlete.

29) Because I am an athlete, I have a mental edge that others might not have.

30) I feel that in my sport, I am encouraged more to achieve success in academics than in athletics.

\section{End of Block: SACSI 2}

Start of Block: Demographics B

Q17 What is your gender identity?

Male

Female

Other (please specify)

Prefer not to answer 
Q18 What is your ethnic/racial identity?

White

Black or African American

Hispanic or Latinx

Asian or Pacific Islander

Native American, American Indian, or Alaska Native

Mixed- or Multi-Racial (please specify)

Other

Prefer not to answer 


\section{APPENDIX B: SACSI FACTOR SCORING KEY}

Factor 1 (Perception of Career Development/Exploration

$2,3,5,6,23,25$

Factor 2 (Career vs. Sport Identity)

$8,9, \underline{\mathbf{1 0}}, 12, \underline{\mathbf{1 3}, \mathbf{1 5}, \mathbf{2 0}, \mathbf{2 4}}, 28$

Factor 3 (Locus of Control)

$\underline{21,22,26,27}$

Factor 4 (Barriers to Career Development)

$\underline{\mathbf{1}, \mathbf{4}, \mathbf{7}}, 16, \underline{\mathbf{1 7}}, 30$

Factor 5 (Sport to Work Relationship)

$11,14,18,19,29$

Note 1: Bold, underlined items are reversed scored prior to interpretation, scoring and data analyses. 